\title{
El gobierno familiar anglo-americano en perspectiva comparada
}

\section{Carole Shammas}

Traductor. Marianne González Le Saux, Maura Lara Altamirano y Benjamín Matamala

\section{(2) OpenEdition \\ Journals}

\section{Edición electrónica}

URL: https://journals.openedition.org/rhj/8409

DOI: 10.4000/rhj.8409

ISSN: 0719-4153

Editor

ACTO Editores Ltda

\section{Referencia electrónica}

Carole Shammas, «El gobierno familiar anglo-americano en perspectiva comparada», Revista Historia y Justicia [En línea], 17 | 2021, Publicado el 11 enero 2022, consultado el 17 mayo 2022. URL: http:// journals.openedition.org/rhj/8409; DOI: https://doi.org/10.4000/rhj.8409

Este documento fue generado automáticamente el 17 mayo 2022.

Revista Historia y Justicia 


\title{
El gobierno familiar anglo- americano en perspectiva comparada
}

\author{
Carole Shammas
}

Tradución : Marianne González Le Saux, Maura Lara Altamirano y Benjamín Matamala

\section{NOTA DEL EDITOR}

$\mathrm{NdT}$ : "Anglo-American Household Government in Comparative Perspective". The William and Mary Quarterly, 52:1, 1995: 104-149. La versión original de este artículo puede encontrarse en: https://www.jstor.org/stable/2946890 y https://oieahc.wm.edu/ publications/wmq/browse/january-1995/. El equipo traductor agradece a la autora Carole Shammas por permitirnos realizar la traducción de su obra y a Joshua Piker, editor del William \& Mary Quarterly por ceder los derechos para su publicación en la Revista de Historia y Justicia. Se han conservado las notas de la versión original con numeración arábiga $(1,2,3)$. Se han agregado explicaciones de los traductores entre corchetes [ ] y notas de traducción al final en numeración romana (i, ii, iii) Si bien se trata de un artículo que ya tiene más de 25 años, propone una clave de interpretación que no ha perdido su vigencia. Su traducción permite acercar al público hispanoparlante a una historia erudita a la vez que sintética del derecho de familia en los Estados Unidos de América, y entrega por tanto bases para poder realizar estudios comparativos en base a los desarrollo historiográficos sobre la historia social y legal de las familias que han tenido lugar en el mundo iberoamericano en las últimas décadas. Además, puede constituir un buen material para la docencia tanto en pregrado como en postgrado para introducir a los estudiantes a los estudios histórico-jurídicos comparados. 


\section{Texto del artículo}

1 Muchas sociedades, tanto en el pasado como en el presente, han recurrido a formas patriarcales de gobierno familiar (en inglés, "household government") para supervisar y disciplinar a su población. Durante los primeros dos siglos y medio del asentamiento Angloamericano, el hogar constituyó el núcleo primario de gobierno para la gran mayoría de los habitantes tales como mujeres casadas, menores de edad, sirvientes y esclavos. Ellos estuvieron sujetos a la autoridad del marido, padre o amo, y en la mayor parte de las familias un hombre blanco era quien ejercía estos roles. Los dependientes tenían una escasa relación directa con el estado mientras dependían del jefe del hogar, y no tenían derecho legal alguno de cortar lazos con este.

2 Desde el siglo XVII con el debate entre Filmer y Locke sobre el parentesco patriarcal, pasando por las teorías sociales y antropológicas sobre los orígenes del estado del siglo XIX, hasta los análisis actuales sobre la ciudadanía, el interés en el gobierno familiar ha girado mayormente en torno a su rol como el prototipo o el espejo de la relación entre el rey y sus sujetos más que en su efectiva función de gobierno. ${ }^{1}$ Historiadores del puritanismo, conscientes de la importancia que se le otorgaba al gobierno de la familia en los folletos protestantes, son quienes han escrito mayormente sobre su funcionamiento: las discusiones reflejan la preocupación de estos mismos folletos respecto de los deberes del jefe en la enseñanza religiosa. ${ }^{2}$ La mayor parte de lo que sabemos sobre los derechos legales y responsabilidades del jefe de hogar vienen de estudios históricos sobre una u otra faceta de esta autoridad: las historiadoras de la mujer investigando el coverture (normas del common law británico relacionadas con el estatus legal de la mujer casada), los historiadores de la familia interesados en la niñez, los historiadores del trabajo examinando las relaciones entre amo y sirviente, y los historiadores sociales trabajando en torno a la esclavitud. Sin embargo, cada vez más académicos se ven interesados por juntar estas relaciones "diádicas" y analizarlas como parte del gobierno familiar como lo hacían sus contemporáneos. ${ }^{3}$

3 En efecto, el concepto de "gobierno familiar" tiene una larga historia. La Política de Aristóteles comienza con una discusión sobre las relaciones de dependencia implicadas en la oikonomike (economía o gobierno del hogar). ${ }^{4}$ Cuando los primeros juristas británicos de corrientes modernas como Mathew Hale y William Blackstone clasificaron las leyes respecto de las personas, tomaron prestada esta tradición griega refiriéndose a los derechos y deberes de amo y sirviente, marido y mujer, padre e hijo, y guardián y menor, como si todos estuvieran bajo "relaciones económicas", concepto bajo el cual se referían a las relaciones del hogar. Trazaron también una distinción entre esas relaciones económicas y aquellas relaciones "políticas" o "públicas" que ejercen reyes, magistrados y cualquier otra persona con la que puedan tener una relación jurídica, aunque ambas implicaban gobernanza y formaban parte del orden civil. ${ }^{5}$ Después de que los teóricos liberales del comercio y la riqueza se apropiaron del término "económico" para referirse a la producción y distribución de bienes y servicios, ${ }^{6}$ los escritores estadounidenses de doctrina legal de fines del siglo XVIII y del XIX optaron por cambiar a la raíz latina del término "hogar", domus, y agruparon estas relaciones de dependencia bajo el concepto de "relaciones domésticas".

4 En los documentos religiosos y políticos de la modernidad temprana diseñados para un público general, el término "gobierno de la familia" surge muy a menudo. Sin embargo, la familia que era "gobernada" no era lo que hoy se considera como familia, esto es, los 
parientes. En ese entonces se refería a las cargas legales residiendo con la persona que tenía poder sobre ellas. ${ }^{8}$

Independiente del concepto usado, la estructura de poder formal dentro de los hogares es uno de los elementos principales que conecta el desarrollo político de la Angloamérica colonial con el de los Estados Unidos. Los desafíos a la autoridad del jefe en sus roles como amo, esposo y padre llegaron a dominar el debate político de mediados del siglo XIX-principalmente los debates sobre el trabajo libre y la abolición de la esclavitud, pero también sobre los derechos de la mujer y la educación obligatoria de los niños. Para la década de los 1860 s, lo que solía ser considerado como problemas familiares para ser resueltos por el jefe de hogar fueron a caer paulatinamente en manos de los tribunales y agencias públicas, en la medida que los adultos dependientes exigieron derechos de ciudadanía y que emergieron las nuevas doctrinas de "separados pero iguales" "ii respecto de las mujeres y los afroamericanos. El cambio forzó gradualmente a los niveles superiores de gobierno, incluyendo al gobierno federal, a asumir una mayor responsabilidad respecto del bienestar económico y social de la población en general. Existe una vasta literatura en torno a la creación del estado de bienestar, y una de sus corrientes relaciona la transición desde la familia como lugar de servicios sociales hacia una situación donde estas funciones fueron asumidas por instituciones públicas. Sin embargo, algo que omiten estas narrativas es aquel sentido de estructura política que subyace a la familia como proveedora de "bienestar". Ha habido una apreciación limitada de la relevancia de la historia del gobierno familiar para la comprensión de la historia general de la política del estado-nación.

6 La desintegración de la autoridad familiar en los Estados Unidos es el tema del presente artículo. ¿Fue este un lento proceso evolutivo donde las condiciones funcionaron desde el principio en contra del firme establecimiento de autoridad sobre los dependientes? El gobierno familiar de la mayoría de las sociedades nativas americanas que los europeos encontraron difería mucho sus propias tradiciones. ¿Qué pasó con esas tradiciones? Las tendencias comunitarias de los disidentes religiosos en el norte y el perfil demográfico del resto de Angloamérica podrían, aparentemente, presentar dificultades para la consolidación del gobierno familiar patriarcal, pero el establecimiento del coverture tradicional y la relación menos tradicional de servidumbre y esclavitud sugieren que las dificultades pudieron ser superadas. ¿Pudo la Revolución Americana, con esa retórica en contra del poder patriarcal y la sujeción, debilitar al gobierno familiar y pavimentar el camino hacia una reducción significativa de la autoridad de maridos, padres y amos? ¿O fue acaso la generación de los Padres Fundadores quienes, temiendo la anarquía, rayaron la cancha para asegurar el poder patriarcal? ¿No fue acaso el amor del republicanismo por un gobierno limitado el que jugó a favor de las soluciones domésticas a problemas sociales? En el ejercicio por balancear algunos de los elementos conflictivos en el hogar que eventualmente explotaron a mediados del siglo XIX, ¿Por qué no adoptaron los angloamericanos algunas de las prácticas de los aparentemente mejor ordenados hogares hispanoamericanos ubicados en lo que se convertiría en la porción suroeste de los Estados Unidos? Al fin y al cabo ¿Qué rol jugaron el mercado o el desarrollo económico -los sospechosos de siempre cada vez que los historiadores investigan las causas de los cambios de larga duración-al momento de explicar el colapso de la autoridad patriarcal? 
7 Es mucho más fácil formular estas preguntas que responderlas. En las siguientes páginas, si bien no puedo garantizar respuestas, trataré de acotar diversas interpretaciones y evidencias contradictorias concernientes al desarrollo del gobierno familiar en los inicios de América. Empezaré con una discusión sobre la autoridad doméstica en la Inglaterra de la modernidad temprana, cuyas características se hicieron tanto más notorias cuando los inmigrantes ingleses se vieron confrontados a la organización del hogar en las culturas nativas americanas. Después de discutir esa confrontación, pasaremos a evaluar los desafíos comunales y demográficos que tuvo el gobierno familiar dentro de los asentamientos angloamericanos en el norte y el sur. Le sigue a esto un análisis de los elementos que operaron para expandir la autoridad de los jefes de hogares en las colonias, reforzándola respecto de lo que existía previamente tanto entre los ingleses como entre los indígenas. Hasta la Revolución Americana, al menos, hubo un limitado, y más bien inexistente movimiento a favor de la desintegración de la autoridad doméstica. Por el contrario, se observa una expansión de los poderes que el jefe de hogar ejercía sobre muchos de sus dependientes. Luego, se revisa el complejo legado de la Revolución Americana, y se discute su sorpresiva falta de efectos a corto plazo sobre la autoridad doméstica, y se considera como problemático el atribuir la desintegración de la autoridad doméstica enteramente al crecimiento económico. Al final del artículo, una comparación entre los hogares de Angloamérica e Hispanoamérica sugiere que las características del linaje y el control sobre el matrimonio y la formación doméstica deberían asumir más importancia para explicar tal desintegración. La atención está centrada en la autoridad legal y los derechos de los miembros del hogar más que en sus relaciones informales. No hay intentos de examinar la totalidad de la experiencia familiar o de resolver preguntas como si el amor de los padres por sus hijos o esposas aumentó o se redujo en el tiempo.

\section{La Autoridad patriarcal doméstica en Inglaterra}

8 Aunque la zona que ahora conocemos como los Estados Unidos ha sido ocupada por diversos grupos culturales con diferentes acercamientos al gobierno familiar, la hegemonía de la corona británica desde los inicios del siglo XVII hasta 1776 asentó el common law y la forma de gobierno familiar que este favorecía en una posición privilegiada, la que continuó incluso después de la formación de los Estados Unidos.

Caracterizar como débil o fuerte el tipo de autoridad que se entendía que los colonos migrantes de las islas británicas en el siglo XVII ostentaban en el hogar depende del punto de referencia que se adopte. El jefe de hogar de la Inglaterra temprano-moderna, tanto como en el resto de Europa, no ejercía poder sobre la vida o la integridad de sus dependientes; no podía tener tantas esposas como se le placiera, tampoco podía forzar a su hijo o hija a casarse, o vender a sus sirvientes. Con el tiempo, las monarquías medievales y la iglesia cristiana, por sus propios motivos, trabajaron en limitar dichas prerrogativas de los patriarcas. ${ }^{9}$ Desde esta perspectiva, los poderes de los jefes de hogar ingleses y sus contrapartes continentales eran débiles en comparación, por ejemplo, con los patriarcas mesopotámicos o romanos. ${ }^{10}$

Ahora bien, el jefe de hogar inglés aliviaba al estado de varias funciones al asumirlas él mismo. El mismo jefe de hogar podía administrar castigos físicos moderados para mantener a sus dependientes en orden. El atentar contra la vida del jefe por parte de la esposa, los hijos o un sirviente constituía "pequeña traición", crimen que era castigado 
por una forma de ejecución peor que aquella aplicada al homicidio simple. Era el jefe de hogar quien decidía la tutela y las necesidades educativas de sus hijos. Él determinaba cuándo un perjuicio a ellos, a su esposa o a sus sirvientes requería de la intervención de un tribunal. Normalmente, no había medios legales para que las esposas pudieran divorciarse, para que los hijos fueran dados en adopción o para que los sirvientes pudieran renunciar antes de cumplido su plazo de servicio. Solo en casos extremos-si la cabecera del hogar asesinaba, mutilaba, o si destituía a sus dependientes-el estado tenía la responsabilidad de intervenir en su favor. Lawrence Stone ha argumentado que en los siglos XVI y XVII el jefe de hogar ejercía mayor autoridad que sus antepasados de fines del medioevo, en gran parte por la Reforma Protestante y las nuevas medidas tomadas por la monarquía y el Parlamento para debilitar el poder aristocrático. Muchos críticos han cuestionado esta tesis en los últimos 15 años, aunque lo más objetado no ha sido su representación de un sistema legal que produjo una "restringida familia nuclear patriarcal" en dicho periodo, sino la forma en la que Stone usa las relaciones legales para hacer conjeturas sobre el ambiente emocional en la familia. ${ }^{11}$

11 Stone argumentó que, en el largo plazo, la Reforma Protestante y el puritanismo aumentaron el poder del jefe de hogar, al reducir la intervención de los sacerdotes y de las cortes eclesiásticas en favor de los dependientes. El estado secular de los TudorEstuardo hizo su parte al disminuir el rol de la costumbre señorial y feudal en la existencia económica y social de la clase de dueños de casa quienes previamente tenían que cumplir las obligaciones de un sirviente [bondsman], villano o de un seguidor con librea [liveried retainers]. ${ }^{i i 12}$ Fue en el área de la legislación sucesoria donde el periodo de los Tudor-Estuardo demostró un incremento dramático de los poderes del jefe de hogar para con su linaje, esposa e hijos. El Statute of Wills de $1540 \mathrm{y}$ posteriores complementos a esta ley permitieron al testador una casi completa libertad de disponer de sus bienes raíces y legar derechos reales para aliviarse de muchas de las restricciones comunes que existían sobre la disposición de la riqueza. Entonces podía desheredar a sus hijos y dejar a su esposa solamente con un interés respecto de un tercio del ingreso de cualquier propiedad raíz que hubiese poseído (su dote [dower]). ${ }^{13}$ La ley sí le exigía que un juez de paz interrogara a su esposa antes de acordar la venta de su propia tierra o la de ella, para verificar su consentimiento en la transacción. El rechazo de la esposa en estas circunstancias ocurría solo en raras ocasiones, principalmente en parejas separadas o que estaban al borde de la separación. A lo largo del periodo, los tribunales del common law restringieron crecientemente las circunstancias bajo las cuales las viudas podían demandar sus derechos dotales [dower rights] sobre la propiedad raíz. ${ }^{14}$

12 El jefe del hogar en los inicios de la Inglaterra moderna tenía la seguridad de saber que la mayor parte de las interferencias de la iglesia, la aristocracia y el linaje carecían de fuerza legal. ${ }^{15} \mathrm{La}$ impotencia del linaje es probablemente la característica más inusual del sistema inglés. No existía una estructura de la propiedad colectiva del linaje ni gobernanza en este aspecto. La obligación por ley de prestar apoyo económico a los hijos recaía únicamente en padres y abuelos, y en ningún otro lazo de parentesco. De la misma forma, los hijos mayores de edad tenían la responsabilidad de apoyar únicamente a sus padres. El jefe de hogar podía enajenar toda su propiedad por línea paterna. Esta autonomía individual del jefe de hogar tenía, sin embargo, un costo: significaba que no podía utilizar ningún mecanismo vinculado al linaje para ejercer su autoridad. 


\section{¿Anarquía Indígena?}

13 Se podría pensar que el gobierno familiar inglés, con su poderoso jefe masculino y con la falta de apoyo de su linaje, no florecería en las colonias americanas. Por un lado, todas las culturas nativas americanas con las cuales los colonos tuvieron contacto distribuían la autoridad familiar de una forma radicalmente diferente. En los primeros años de la colonización, cuando la población indígena excedía a la de los inmigrantes y migraba un número limitado de mujeres inglesas, se podría esperar que los conceptos indígenas de la organización doméstica hayan alterado o transformado las prácticas inglesas. Así, una repugnancia inicial [a estas formas de organización doméstica] podría haberse visto seguida de una acomodación.

14 Ciertamente, dicha repugnancia puede ser documentada. Los ingleses, así como los españoles en el sur y el sureste y los franceses en Canadá y la región de los Grandes Lagos, consideraron que, de todas las diferencias que tenían con los nativos, las prácticas domésticas de los indios eran las más desconcertantes y perturbadoras. Cualquier cosa que diferenciara a los europeos entre sí respecto a la organización familiar palidecía frente a la diferencia que tenían con los indígenas. Y, de lo que se conoce sobre las variadas culturas indígenas tras el contacto y conquista de los europeos, los habitantes nativos consideraban a las nociones europeas sobre el gobierno familiar igualmente extrañas.

15 Los exploradores de los inicios de la Europa moderna, misioneros y colonos comentaban con frecuencia ciertas características de la organización doméstica de los indios, y los problemas ya presentados emergían ya sea que el observador fuera inglés, español o francés o que el grupo indio en discusión fueran los algonquinos o los iroqueses, los dos grupos más comunes en la costa este y en los Grandes Lagos, o los pueblos de habla siouan, en el sureste, o los indios Pueblo, en lo que más tarde sería el suroeste de los Estados Unidos. James Axtell ha recolectado muchas de estas quejas en su antología The Indian Peoples of Eastern America [Los pueblos indios del este de América].$^{16}$ En la década de 1630 el párroco francés Gabriel Sagard comentaba que las mujeres hurón hacían "más trabajo que los hombres (...) Ellas tenían que hacerse cargo de la comida y del hogar, de la siembra y cosecha del maíz, del proceso de creación de la harina, preparar el cáñamo y las cortezas de árbol, además de proveer la madera necesaria". Haciendo eco de lo dicho por Champlain: "Ellas se preocupaban de casi todo lo referente a la casa y el trabajo (...) y por otro lado son requeridas para seguir y acompañar a sus esposos de lado a lado (...) donde servían como mulas para cargar el equipaje". William Wood, un caballero inglés, caracterizó a las mujeres algonquinas del sur de Nueva Inglaterra como "más trabajadoras de sus flojos esposos". Los hombres micmac en Maine tuvieron una reputación igualmente mala. Entre los delawares y los miamis, según David Zaisberger, misionario de finales del siglo XVIII, "en el manejo de los asuntos hogareños el marido deja todo en manos de su esposa". El padre Joseph Lafitau asumió que entre los iroqueses "los hombres, quienes son tan ociosos en sus villas, hacen de su indolencia una marca de honor". ${ }^{17}$ Observaciones similares han aparecido en otros historiadores de los grupos indios de la América temprana. El duro trabajo puertas afuera de las mujeres powhatan del siglo XVII acarreó fuertes críticas por parte de los colonos de la Compañía de Virginia. Según el cronista George Alsop, entre los susquehannocks de Pennsylvania "las mujeres son las carniceras, cocineras y trabajadoras de la tierra (...) los hombres consideran por debajo del honor masculino el 
agacharse ante cualquier cosa que su arma, o arco y flecha no pudieran comandar". La población blanca claramente desaprobó la división del trabajo en los ríos de Georgia y Alabama; el tratado de 1790 especificaba que los hombres creek sanos ya no tenían permitido evadir trabajos referidos a la agricultura y ocuparse en actividades "ociosas" como cazar, pescar y jugar a la pelota mientras las mujeres cortaban madera y acarreaban agua. Los misioneros quaker y luego el gobierno federal trabajaron duro para transformar a los hombres de la tribu Seneca en granjeros. De la misma forma, solo un par de siglos antes, los franciscanos de Nuevo México buscaron enderezar a los indios Pueblo por medio de colocar a los hombres a cargo de la construcción de casas, mientras las mujeres se encargaban de la costura. ${ }^{18}$

Historiadores han revelado las concepciones erradas que se esconden tras estos comentarios y acciones. Axtell se esfuerza en argumentar en contra de los sesgos de Europa occidental. Discute la exhaustiva y peligrosa naturaleza de la caza, la ausencia de cronistas europeos en el invierno cuando la mayor parte de esta caza ocurría, y la tendencia de los europeos a pensar en la pesca y la caza como actividades propias del ocio más que como unas funciones económicas primarias. Por otro lado, Axtell sugiere, que la mayor parte de los quehaceres de las mujeres "eran razonablemente ligeras y realizadas cerca de la casa.” Básicamente, la contribución económica de cada sexo era igual. $^{19}$

17 Sin embargo, la evaluación europea de las desigualdades de género iba más allá de sus diferentes conceptos sobre el trabajo. ¿Cuál era la lógica detrás de la insistencia de los europeos en que el hombre tomara los trabajos de la tierra y realizara ciertos tipos de tareas en el hogar tales como cortar madera? Es difícil pensar que los europeos se preocuparan mucho por las duras labores que recaían sobre las mujeres indias. Los hombres europeos tenían pocos problemas cuando se trataba de hacer que mujeres sirvientas o esclavas, de cualquier etnicidad, trabajaran en los campos. De hecho, algunos comentaristas no pensaban que las mujeres indias trabajaban lo suficientemente duro y sugerían que no eran muy rigurosas en la limpieza y cuidado del hogar. ${ }^{20}$ En cambio, la disconformidad europea con los roles de género de las sociedades indígenas parecía centrarse en el compromiso y contribución que el hombre hacía en el hogar, con lo que se referían a la unidad compuesta por la esposa y los hijos. Los hombres indígenas no se hacían cargo de su hogar como lo hacían los europeos.

18 La mayoría de las culturas que los europeos encontraron eran matrilineales. La descendencia era calculada y la identidad obtenida por las parientes maternas. Algunas culturas indígenas que seguían las reglas de la descendencia patrilineal de todas formas mantenían la matrilocalidad en su residencia: un esposo y los hijos que tuviera con su esposa vivían en el pueblo o en la sección del pueblo donde residía la familia de la esposa. Incluso donde no prevalecía la tradición matrilineal ni la matrilocal, los utensilios de la casa y el hogar eran considerados, comúnmente, propiedad de la mujer. Richard White, discutiendo los algonquinos de los Grandes Lagos, apuntó a uno de los efectos de estos patrones de parentesco y descendencia. "Dependiendo de la identidad tribal de la mujer," escribe, "una mujer algonquina tenía a menudo una relación más duradera y significativa con su madre, padre, hermanos, hermanas o abuelos, o incluso con otras mujeres no relacionadas por parentesco que con su esposo o esposos". ${ }^{21}$ Otro efecto, según los antropólogos e historiadores, era que los hombres casados, incluso si tenían una esposa a la vez-y este parecía ser el caso en la mayoría de los hombres indios sin importar la tribu-tenían obligaciones con más de un hogar: con el de su 
esposa e hijos, y con el o los hogares asociados con su línea materna. ${ }^{22}$ Tales obligaciones podían tomar la forma de un hombre otorgando los productos de su trabajo, volviendo a su hogar natal para ceremonias, o asumiendo los deberes del líder del clan y residiendo permanentemente con el matrilinaje. El avance en el clan, villa y clan dependía de su relación con sus parientes maternos, no con aquellos asociados con su unidad conyugal. A este respecto, las lealtades de las mujeres estaban menos divididas, porque residían con o cerca de su linaje matrilineal, lo que también les daba a ellas-y a sus hijos-su identidad. Una mujer era, como lo dijo un jesuita a principios del siglo XVIII, "dueña" y "heredera" de su tienda o carpa. ${ }^{23} \mathrm{Si}$ era ella quien cargaba su hogar sobre su espalda cuando la tribu se mudaba, era posiblemente porque era ella quien tenía los derechos sobre este. Si trabajaba en los campos, era posiblemente porque se trataba de los campos pertenecientes a su propio linaje.

Esta percepción de la lejanía masculina y del compromiso limitado con la unidad familiar conyugal también se asoma detrás de otras quejas-falta de disciplina sobre los niños, promiscuidad sexual femenina y divorcio fácil-comúnmente presentadas contra la vida familiar indígena a principios del período moderno. En los reportes contemporáneos, las madres no solo cuidaban a los niños sino que también tenían la principal autoridad sobre ellos. Para desesperación de los observadores europeos, solo las madres indígenas cristianizadas se abocaban al castigo físico de sus hijos. El padre era de poca ayuda. Según un reporte relacionado, él tenía afecto por sus hijos "traviesos", pero participaba poco en formarlos como adultos responsables. La formación y educación de los hijos varones a menudo recaía en los hombres de la línea matrilineal, no en el padre. ${ }^{24}$ Debido a la libertad sexual de las mujeres solteras y al divorcio fácil, los esposos, temían los observadores europeos, podrían ni siquiera haber engendrado a los hijos de sus consortes. Los matrimonios terminaban por consentimiento mutuo, y cada parte se iba con otra persona. La autoridad doméstica del hombre era, como lo expresan estos comentaristas, muy limitada, ya que sus hijos podían ignorarlo, no podía controlar la sexualidad de las mujeres en el hogar, y su esposa podía dejarlo o, más probablemente, expulsarlo. ${ }^{25}$

Los europeos no podían entender cómo se podrían modelar sociedades estables a partir de unidades de hogares tan inestables. Para un analista de principios del siglo XVIII, el "aislamiento y la debilidad numérica de la raza" podrían atribuirse a este sistema familiar. "Las mujeres, aunque naturalmente prolíficas, no pueden, debido a su ocupación en estas labores, dar a luz una descendencia completamente desarrollada o alimentarla adecuadamente después de haber dado a luz". Para otro observador, el sistema se asimilaba al de una "bestia bruta"; otro más afirmó que "debido a la inestabilidad de la relación familiar, los niños a menudo son descuidados", a pesar de que los indios los amaban bastante. Muchos comentaristas escribieron sobre el frecuente recurso al aborto para manejar la carga de trabajo de la crianza. ${ }^{26} \mathrm{La}$ familia indígena se convirtió en la primera de una serie de sistemas familiares que chocaron con las ideas euroamericanas sobre el gobierno familiar. Los sistemas en los que se dispersaba la autoridad, a menudo alojados parcialmente en grupos de linaje en lugar de ejercerse solamente dentro de la unidad doméstica, o donde la familia se centraba en la madre y el hijo en lugar del vínculo conyugal, tendían a considerarse inviables. Es posible que los ingleses, al conocer solo la debilidad de sus propias conexiones de parentesco, encontraran la confianza de los indios en el linaje especialmente desconcertante. 
21 Al mismo tiempo, el sistema familiar indígena tenía algunas características atractivas, especialmente para los hombres europeos que enfrentaban altos índices de masculinidad en sus propios asentamientos. Virginia temprana tenía una proporción de sexos de 7 hombres a 1 mujer. Incluso en las colonias mejor equilibradas de Nueva Inglaterra, la proporción se situó en 1.5 a 1. Con el tiempo, las proporciones tendieron a la igualdad, excepto en la frontera, donde los asentamientos indígenas eran más numerosos. ${ }^{27}$ Además, los hombres atraídos a la vida en tierras "salvajes" podrían considerar como atributos muy atractivos no solo la disponibilidad sexual de las mujeres indias, sino también los contactos que les proporcionaron con los asentamientos indios, su autosuficiencia económica como esposas y las disposiciones de divorcio fácil. Por lo tanto, lo que en el nivel macro puede haber parecido indeseable para los líderes coloniales, en el nivel micro puede haber parecido más atractivo para los colonos varones. La composición genética de la mayoría de los residentes de las Américas hoy es un monumento a la capacidad de estos factores para superar las percepciones de diferencia cultural.

Sin embargo, las parejas interraciales tuvieron que enfrentar una considerable oposición legal en las colonias británicas. En Virginia, los registros indican solo dos matrimonios mixtos legalmente sancionados después de la boda de John Rolfe y Pocahontas en 1614. En 1691, la Cámara de los Burgueses aprobó una ley que prohibía los matrimonios entre "blancos y negros, mulatos o indios". ${ }^{28}$ En 1741, la legislatura de Carolina del Norte impuso una multa de cincuenta libras a cualquier persona blanca que se casara con un "hombre o mujer indio, negro, mestizo o mulato, o cualquier persona de sangre mezclada hasta la Tercera Generación, esclava o libre". ${ }^{29}$ Un investigador moderno afirma que el registro histórico tampoco indica la presencia de matrimonios coloniales legales entre un hombre de Nueva Inglaterra y una mujer india en el siglo XVII. En Connecticut, en 1642, quienes huyeron de los asentamientos para "ocupar su morada con los indios en un curso de vida profano" enfrentaron tres años de prisión y posibles multas y castigos corporales. En 1680, el sínodo de las iglesias congregacionales decretó que los cristianos no podían casarse con "infieles". Considerando los extremadamente débiles esfuerzos misioneros de Nueva Inglaterra, este mandato, en efecto, evitó que la mayoría de las parejas interraciales se casaran bajo la ley inglesa. ${ }^{30}$

23 En contraste, muchas sociedades indígenas inicialmente aceptaron los matrimonios mixtos. Estaban acostumbrados a las uniones exógamas hechas con fines de alianza. Las sociedades indígenas matrilineales esperaban que los niños y su educación recayeran en la madre, que en la mayoría de los matrimonios interraciales era india. Un funcionario inglés a fines del siglo XVIII se quejó de que un hombre blanco que se casaba con una mujer india de la nación Creek, "lejos de mejorar su condición, se convierte en esclavo de su familia". ${ }^{31}$ Sin embargo, en las zonas donde los indios y los blancos comerciaban entre sí, había muchos de estos hogares mezclados. Aunque los desastres demográficos sufridos por las poblaciones nativas americanas obstaculizaron la propagación de su forma de gobierno familiar, ${ }^{32}$ el impacto de la hostilidad legal inglesa a su sistema familiar y la etnogénesis no deben subestimarse. Más tarde, los líderes indios varones también se volvieron más hostiles hacia la mezcla con los euroamericanos en las colonias británicas, viéndolos como una amenaza para la continuación de las naciones indias..$^{33}$ Los hijos de las uniones mixtas tenían que identificarse con una cultura $\mathrm{u}$ otra. No emergió ningún grupo cultural 
conscientemente nuevo, y no se produjo la inclusión de las normas domésticas indias dentro de las tradiciones coloniales del gobierno familiar angloamericano.

En la América hispana, ni la iglesia católica ni las autoridades seculares mostraron tanto celo en detener las uniones interraciales o la identificación con una tradición cultural mixta. ${ }^{34}$ Lo que es incierto es el grado en que esta actitud más indulgente puede explicar las desviaciones de la práctica española, como la alta tasa de hogares encabezados por mujeres observado en muchos países latinoamericanos en el siglo XIX, $\mathrm{u}$ otras manifestaciones de una familia con una orientación menos conyugal entre poblaciones mestizas. ${ }^{35}$

La contribución más obvia de la organización de los hogares indígenas a la evolución de las estructuras políticas se produjo más tarde en el siglo XIX. Los teóricos como Lewis Morgan y Friedrich Engels utilizaron la investigación sobre el parentesco indígena para criticar a la familia victoriana en los Estados Unidos y Europa occidental, así como las explicaciones patriarcales sobre el origen del estado. ${ }^{36}$ Las características del linaje matrilineal y corporativo de las culturas indígenas nunca se volvieron dominantes en los Estados Unidos, pero los intelectuales y los defensores del cambio social los usaron para socavar las formas prevalecientes de gobierno familiar angloamericano.

\section{El gobierno familiar inglés enfrenta el proceso de asentamiento}

Los archivos dejados por los jefes de hogar del siglo XVII viviendo en Angloamérica tienen poco que decir respecto de los habitantes nativos. Estos dedicaron mucho más espacio a los problemas del gobierno familiar dentro de sus propios grupos culturales ocasionados por la migración. Los problemas diferían, dependiendo de si uno vivía en una sociedad sureña dedicada a la plantación como la Chesapeake [Virginia] o en una colonia de disidente religiosos del norte [por ej. Massachusetts].

Las dificultades encontradas por los habitantes de Chesapeake han sido exploradas con cierta detención durante las últimas dos décadas, y no voy a ahondar en ellas aquí. Cuando los estudios demográficos del área revelaron la elevada tasa de hombres sobre mujeres, y los altos índices de mortalidad de las comunidades dedicadas a la plantación en el siglo XVII, los académicos investigaron las consecuencias que ello tuvo sobre la autoridad doméstica tradicional. La incapacidad de los padres, debido a su corta expectativa de vida, para supervisar las carreras y los matrimonios de sus hijos, la necesidad de los maridos de ofrecer dotes comparativamente generosas para las muydemandadas esposas, la oportunidad que las viudas saludables y mujeres acaudaladas tuvieron para dirigir los negocios familiares en ausencia de herederos masculinos apropiados, y los problemas que los amos experimentaron en la tarea de evitar la amenaza de que sus sirvientes se transformaran en amenazas al orden público han sido identificadas como parte de la historia del gobierno familiar en el siglo XVII en la región y en general en las sociedades de plantación. ${ }^{37}$

28 En las colonias disidentes de Nueva Inglaterra y Pennsylvania, donde todos excepto los primeros colonos gozaron de una expectativa de vida mayor que en Inglaterra y tenían una proporción de sexos más balanceada que en las colonias dedicadas a la plantación, la amenaza para la autoridad del hogar emanó de una fuente distinta, una que las investigaciones anteriores no han visto necesariamente como una amenaza. Los 
clérigos puritanos entregaron una nueva importancia a conceptos como el gobierno familiar y la autoridad de su jefe. Sin embargo, cuando estos feligreses religiosamente inspirados emprendieron la tarea de erigir una sociedad cercana a Dios en el nuevo mundo, los jefes de hogar no escaparon a la vigilancia que estas comunidades bíblicas ejercían sobre todos sus habitantes. ${ }^{38}$ Las normas de la comunidad solían ser superiores a aquellas del hogar.

29 Probablemente la confrontación más dramática entre ambas fuentes de autoridad ocurrió en la colonia de Plymouth. Como ha apuntado Mary Beth Norton, el subtexto en la conocida historia del colapso del comunitarismo entre los Padres Peregrinos [Pilgrims] es en realidad la historia de la autoafirmación del gobierno familiar. Los hombres jóvenes se quejaban de tener que "gastar su tiempo y fuerza en trabajar para las esposas e hijos de otro hombre sin ninguna recompensa", los hombres más fuertes no recibían más provisiones que los hombres más débiles, los "hombres de más edad y consideración siendo clasificados e igualados en labores y víveres, ropas, etc. con los más jóvenes y miserables", y el forzamiento de las esposas de "hacer el servicio" para hombres distintos de su marido, preparando su comida y lavando su ropa, todo ello surgió de la violación del principio de que el servicio y las recompensas de ese servicio debían ser organizados y distribuidos dentro de la estructura hogareña. El hombre joven esperaba trabajar ya sea para su padre o para un amo que le ofreciera un salario. Los hombres mayores de más consideración estaban acostumbrados a encabezar un hogar donde él supervisaba los recursos y el trabajo de los jóvenes y las mujeres adultas. Una esposa asumía que sus servicios domésticos se extendían solamente a los miembros del hogar. Plymouth reinstauró rápidamente una forma más ortodoxa de gobierno familiar, y los otros asentamientos disidentes en el siglo XVII no repitieron el experimento. ${ }^{39}$ Sin embargo, las colonias de Nueva Inglaterra y Pennsylvania erigieron otros mecanismos que circunscribieron el poder del jefe del hogar en virtud de perseguir objetivos comunitarios. Algunos de estos mecanismos empoderaron a los dependientes, otorgándoles más derechos. Otros, destinados a reforzar las cabeceras de hogar laxas o débiles, resultaron en una mayor y más rigurosa vigilancia de los dependientes. El objetivo último, en ambos casos, era la estimulación de una comunidad más piadosa y cercana a Dios, no de las libertades individuales.

30 Los dependientes del hogar ganaron poder de varias formas. La prohibición del castigo físico sobre la esposa en la Bahía de Massachusetts y la autorización del divorcio absoluto (que permitía a la parte inocente volver a contraer matrimonio) en toda Nueva Inglaterra redujeron la autoridad otorgada por la ley a los esposos. En todas estas colonias, las peticiones de divorcio por parte de las mujeres fueron mayores en número que aquellas de los hombres, indicando la utilidad de este mecanismo de compensación para las mujeres bajo el coverture..$^{40}$ Mucho antes que en cualquier otra colonia o en Inglaterra, la legislación puritana requería que padres y amos enseñaran a sus hijos y sirvientes a leer e hicieron activamente cumplir estos mandatos. ${ }^{41}$ Las leyes de Nueva Inglaterra y Pennsylvania sobre la sucesión abintestada [herencia sin testamento] también estimularon una distribución más igualitaria de la herencia entre los hijos, reduciendo la cuota de bienes inmuebles del primogénito a una porción doble en vez de la porción completa que habría recibido bajo la tradición más dinásticamente orientada del common law.

31 Con todo, los efectos de estas medidas que mejoraron los derechos de los dependientes respecto de la cabecera del hogar fueron limitados. Los divorcios afectaron a pocos 
hogares de Nueva Inglaterra en el siglo XVII. Las autoridades concedían uno al año, en promedio. ${ }^{42}$ Se han levantado dudas sobre cuán frecuentemente los oficiales de la ciudad efectivamente persiguieron los casos de maltrato contra la mujer, porque los casos registrados son muy escasos..$^{43}$ Las disposiciones sobre educación especificadas en las normas de Nueva Inglaterra no requerían que padres y amos dedicaran buenos años de trabajo para educar a sus jóvenes dependientes. Los padres podían escribir testamentos y deshacer aquellas disposiciones más igualitarias de las muertes abinstestadas.

32 Lo que sí afectó a gran parte de los hogares del siglo XVII fue la supervisión sobre los jefes de hogar negligentes para asegurar que el orden familiar fuera mantenido. Irónicamente, la absorción por parte de las autoridades puritanas de los deberes patriarcales del jefe de hogar solía colocar mayores restricciones sobre las acciones de los dependientes y castigaban transgresiones más severamente de lo que hubiera sido bajo el régimen tradicional del gobierno familiar. Oficiales de Massachusetts colocaron en operación un sistema de tithingmen o inspectores para asegurar que los habitantes no burlaran las disposiciones que obligaban a un buen gobierno familiar. Un tithingman supervisaba entre 10 y 12 familias en un vecindario y reportaba a los hijos obstinados o desordenados, sirvientes díscolos, aquellos que no respetaban el descanso dominical, a los bebedores y a quienes merodeaban las calles de noche. ${ }^{44}$ Estos oficiales eran parte de una impresionante formación de dignatarios eclesiásticos y oficiales civiles localesmagistrados, sheriffs, agentes de policía, guardias, jurados mayores, guardianes de los pobres y concejales [selectmen]-cuyos deberes incluían supervisar la moral y los modales de la población. ${ }^{45}$

33 En la temprana Pennsylvania, también una colonia disidente, los mecanismos para asegura el orden del hogar entre los piadosos tomó la forma de las "Quaker meetings" [reuniones de los cuáqueros] las cuales tenían unidades de hombres y mujeres. Las Quaker meetings en América disuadían a los amos de adquirir esclavos, disciplinaban a los esposos y padres en el abuso de las esposas y los hijos, castigaban el coito por medio de ordenar al seductor casarse con la seducida, desautorizaban a los padres para detener un matrimonio, forzaban a aquellos casados con no-cuáqueros a dejar las reuniones y obligaban a las familias a mudarse para escapar de las influencias pecaminosas. ${ }^{46}$

34 Según las diversas fuentes, estos guardianes del orden del hogar cumplieron con el efecto esperado. La investigación sobre las infracciones se relaciona principalmente con Nueva Inglaterra, y en dicho lugar, en el transcurso del siglo XVII, vivía un grupo de personas ciertamente muy respetuosas de la ley. En el área de los delitos sexuales, ha sido demostrado que los habitantes exhibieron cifras muy bajas de fornicación y de nacimientos bastardos comparadas con otras colonias británicas o con la propia Inglaterra durante este periodo. ${ }^{47}$ Este fue el caso incluso con una numerosa población en riesgo de cometer infracciones, considerando el interés de los disidentes en hacer tanto al hombre como a la mujer responsables de las prácticas sexuales ilegales.$^{48}$ Ahora bien, no puede decirse que las mujeres como grupo hayan sido necesariamente beneficiadas por este incremento de la vigilancia. Una vez que las autoridades empezaron a entrometerse en los asuntos del hogar y a etiquetar como crimen ciertas cosas como el embarazo premarital y vivir fuera del gobierno familiar, los dependientes, como una categoría en la cual muchas mujeres caían, estaban bajo un alto riesgo de ser reportados por aquellas excepcionales infracciones que cometían. ${ }^{49}$ 
Así, el crimen más comúnmente procesado en los juzgados de condado de Nueva Inglaterra a lo largo de todo el periodo colonial fue la fornicación, un delito que casi siempre implicaba a mujeres mas no siempre a hombres. ${ }^{50}$ La fornicación era un crimen bastante común dado que incluía no solo a una mujer soltera que quedaba embarazada, sino también a las parejas casadas que tenían hijos antes de haber estado casados por nueve meses (donde se podía presumir coito premarital). La masificación del puritanismo en Inglaterra animó este tipo de procesamiento, pero solo algunas parroquias emprendieron la práctica de castigar criminales casados..$^{51}$ En la Nueva Inglaterra puritana, sin embargo, el procesamiento fue más universal y duradero. En la medida en que la fornicación se hizo más y más común a fines del siglo XVII, la proporción de crímenes atribuidos a mujeres aumentó; para la década del 1690, casi un tercio de los criminales de Nueva Inglaterra y Massachusetts eran mujeres, mientras en Connecticut alrededor de uno de cada cinco de aquellos perseguidos eran mujeres ${ }^{52} \mathrm{En}$ cuanto a crímenes serios, el porcentaje de mujeres de Nueva Inglaterra acusadas durante el siglo XVII aumentó a niveles históricamente altos, dado que la sociedad investigaba con mayor celo la muerte de infantes, las acusaciones de brujería, y los cargos por infidelidad dentro del matrimonio. Dados estos cargos, las mujeres compusieron el 33 por ciento de los acusados por crímenes graves de Massachusetts en los 1670 s, 39 por ciento en los 1680 s, y 60 por ciento en los 1690s (sin incluir los procedimientos especiales de la corte de Salem). En contraste, las tasas de crímenes graves cometidos por mujeres en los Estados Unidos en el tercer cuarto del siglo XX rondaban entre el 9 y el 19 por ciento..$^{53}$

¿Acaso las cabeceras de hogar no verían con buenos ojos esta asistencia por parte del estado en la mantención del orden sobre sus dependientes? Indudablemente, bajo ciertas circunstancias, las actividades de las congregaciones puritanas, los tithingmen, los selectment y las Quaker meetings sirvieron los propósitos de los amos, esposos, o padres. Los amos apreciaban saber cuando sus sirvientes estaban merodeando la ciudad en vez de hacer su trabajo. Los esposos querrían ser informados sobre el comportamiento adúltero de sus esposas y podrían tomar ventaja de que las leyes de divorcio de Nueva Inglaterra les permitiese liberarse de una esposa desleal. Los jóvenes, en conocimiento de que el castigo por la fornicación y dar a luz a un bastardo sería público y doloroso, ya sea física o financieramente, lo pensarían dos veces antes de embarcarse en aventuras sexuales, y esta vacilación servía los intereses casamenteros de los padres. Pero, por otro lado, ¿qué padre estaría genuinamente satisfecho cuando debía presentarse ante un tribunal con su hija para pagar la multa por fornicar, conociendo que tal multa lo haría más pobre y debilitaría las probabilidades de que su hija lograra un matrimonio del cual pudiera sacar ventaja? Incluso menos bienvenidos serían los esfuerzos incansables de un oficial local para investigar la acusación interpuesta por una sirviente mujer acusando al jefe de hogar de ser el padre del bastardo que ella esperaba, o la acusación interpuesta en su contra por un sirviente hombre por el cargo de sodomía. De un modo similar, una acusación de que su esposa era una bruja raramente implicaría una mejor reputación para el jefe de hogar dentro de la comunidad. En Pennsylvania, la insistencia de las Quaker meetings en el matrimonio dentro de la comunidad y entre seductores y seducidas generaba conflictos con los intereses dinásticos del jefe de hogar. Asimismo, los amos que trataban de componer una fuerza de trabajo estable podrían resentir la desaprobación de la esclavitud entre los cuáqueros. Los jefes de hogar, quienes ejercían su derecho de administrar el castigo físico "moderado" a su esposa e hijos, podrían objetar la 
interferencia del comité de amigos quienes tenían una definición distinta de aquello que es moderado. En suma, cuando las autoridades estatales se hicieron cargo de labores que estaban caracterizadas como patriarcales, sus acciones y sus intereses a veces divergían de aquellos de los jefes de hogar patriarcales, disminuyendo antes que reforzando la autoridad de este último.

¿Deberíamos concluir, entonces, que la migración a Norteamérica inició una tendencia de larga duración hacia un jefe de hogar con cada vez menos autoridad doméstica? Probablemente no. En las colonias del sur, las peculiaridades demográficas-alta mortalidad y altos índices de masculinidad-que debilitaron el control patriarcal empezaron a desaparecer a finales del siglo XVII, debilitando cualquier poder que las mujeres adultas y los menores pudieron haber tenido derivados de la situación anterior..$^{54}$ En las colonias disidentes del norte, el tiempo también trajo consigo una disminución en el grado de interferencia comunitaria padecida por los jefes del hogar.

Para mediados del siglo XVIII, por ejemplo, las autoridades en la mayoría de las ciudades dejaron de perseguir parejas casadas por fornicación y redujeron la severidad del castigo entre los no casados. La incidencia de la sexualidad no marital vino a asemejarse más cercanamente a otras comunidades angloamericanas. ${ }^{55}$ Mientras que los historiadores del cuaquerismo no indican ninguna disminución en el rol supervisor de las reuniones, la proporción de población de las colonias del centro bajo su control disminuyó constantemente. A diferencia de Europa y Latinoamérica, ninguna de las colonias angloamericanas tuvo cortes eclesiásticas o burocracias religiosas para reforzar la moralidad y limitar el poder del jefe de hogar.

\section{La expansión del gobierno familiar patriarcal}

38 Muy probablemente el gobierno familiar se fortaleció a lo largo del periodo colonial, y debemos culpar a la abundancia de tierras de asentamiento y la diversidad religiosa por su desarrollo. La alta tasa de tierra disponible respecto de la mano de obra empoderaron a los amos y aumentaron los costos para las instituciones públicas que competían con los jefes de hogar por la autoridad. El incremento de la diversidad religiosa también tuvo un efecto amortiguador en las instituciones públicas, dado que previno a la población colonial de adoptar el modelo europeo en el que una iglesia establecía instituciones legales, educacionales y de bienestar que intervenían en el gobierno familiar. En diversos grados, este fenómeno afectó tanto a las poblaciones de las colonias del norte como las del sur.

Una de las temáticas más recurrentes en la historia de los Estados Unidos es el efecto emancipador de la tierra disponible. El acceso extendido a la tierra es normalmente considerado como una amenaza al control del jefe de hogar sobre sus dependientes. Sin embargo, los efectos de la disponibilidad de la tierra no son unívocos. Ciertamente, se correlaciona de manera estrecha con una disminución de la edad legal para contraer matrimonio y una alta fertilidad, implicando libertad para los hijos. ${ }^{56}$ Sin embargo, no necesariamente la tierra no ocupada es siempre tierra disponible. Solo en ciertos momentos y lugares pudieron los jóvenes angloamericanos migrar libremente y explotar los recursos naturales del continente a saciedad..$^{57}$ Establecer un hogar por separado sin la asistencia de generaciones anteriores suponía una gran dificultad. Pero el mayor problema respecto de la ecuación entre la tierra y la libertad personal es que en América la abundancia de tierra condujo tan obviamente a la esclavitud. Para 
asegurar una fuerza de trabajo para la producción de un cultivo rentable, los colonos adoptaron sistemas de servidumbre forzada [indentured labor] y luego de propiedad esclavista, por lo cual un amo ganaba mayores derechos sobre sus sirvientes de los que hubiera tenido en el viejo mundo.

40 La mayor proporción de tierra respecto de la mano de obra fue también un factor en la predilección de los angloamericanos por utilizar el hogar en vez de las instituciones públicas para solucionar problemas sociales y económicos. Una razón para ello radica en el beneficio mutuo que reportaba a la comunidad blanca libre y a los amos el convertir los casos de personas indigentes en relaciones de servidumbre ligadas al hogar. Una segunda razón fueron los altos costos de servir una comunidad dispersa.

41 La diversidad religiosa es otro equivalente a la libertad que parece haber limitado el crecimiento de las instituciones públicas en el siglo XVIII. Inicialmente las colonias disidentes hicieron una inversión relativamente grande en estructuras de bienestar público (centros cívicos, universidades y escuelas). Se habría podido proyectar un estado de bienestar naciente, una proto-Suecia, que continuaría vigilando y terminaría por usurpar la autoridad de los jefes de hogar. Sin embargo, mientras pareciera que las colonias como Massachusetts continuaron excediendo los niveles de gasto social de la mayoría de las otras provincias, no parece que se haya mantenido en el tiempo el impulso de construcción comunitaria. ¿Qué ocurrió? El episodio de brujería en Salem ilustra este punto, mostrando que la vigilancia para asegurar que el jefe de hogar estaba manteniendo a sus dependientes a raya podía ser disruptivo y causar divisiones incluso dentro de una comunidad de verdaderos creyentes. La base social de apoyo que favorecía el establecimiento de instituciones públicas que confirmaran los estándares de moralidad, educación y bienestar disminuyeron en la medida en que la población se diversificó religiosamente y se volvió más suspicaz de la religión dominante.

Aunque estas explicaciones para la expansión del gobierno familiar en el nuevo mundo son especulativas, la expansión en sí misma está claramente documentada. Aquellos estratos pobres de la sociedad que en Europa hubieran encabezado sus propios aunque modestos hogares, en Angloamérica fueron incorporados a los hogares de otros, eliminando mágicamente la desigualdad en riqueza y la pobreza ${ }^{58} \mathrm{y}$ concentrando el poder de los jefes del hogar en unas pocas manos. Aunque tendemos a pensar en Gran Bretaña y Europa occidental como teniendo una estructura social más jerárquica en este periodo, una proporción notablemente más alta de personas en las Américas, incluyendo Angloamérica, cayeron dentro de la categoría de dependientes legales.

43 La Tabla 1 compara la proporción de dependientes de las poblaciones de Inglaterra y Gales y de las trece colonias angloamericanas en la última parte del siglo XVIII: 68 por ciento en Inglaterra y Gales en 1755; 80 por ciento en las colonias en 1774. Notemos que el restante 20 por ciento de la población no consistía enteramente en jefes de hogar. Algunas eran madres viudas viviendo con sus hijos adultos, o hijos adultos viviendo con los padres, o adultos no casados. Estos grupos habrán sido económicamente dependientes, pero tenían el derecho legal de dejar el hogar. La alta fertilidad en el territorio que pronto se convertiría en los Estados Unidos explica parcialmente el porqué de la creciente dependencia. Y cuando eliminamos a los menores y nos centramos solo en la población adulta, las trece colonias se adelantan nuevamente, 54 por ciento comparado con un 40 por ciento en Europa. Más significativamente, 26 por ciento de la población adulta total en las colonias eran sirvientes y esclavos, 
comparados con el 7 por ciento en Inglaterra y Gales. Cien años después, la mayor parte de las formas de dependencia adulta habrían desaparecido.

Tabla. 1: Dependientes legales en Inglaterra y en las colonias americanas, 1755 y 1774 (en miles)

\begin{tabular}{|c|c|c|}
\hline & $\begin{array}{l}\text { Inglaterra y Gales } \\
\text { (1755) }\end{array}$ & $\begin{array}{l}\text { Colonias norteamericanas } \\
(\mathbf{1 7 7 4 )}\end{array}$ \\
\hline Menores (bajo los 21 años) & 2978 & 1343 \\
\hline $\begin{array}{l}\text { Hijos y sirvientes empleados } \\
\text { [hired servants] }\end{array}$ & $\mid-----$ & 1034 \\
\hline Contratos forzosos [indentured] & $\mid-----$ & $27^{\text {(c) }}$ \\
\hline Esclavizados & $\mid-----$ & 282 \\
\hline Esposas $^{(a)}$ & 1088 & 292 \\
\hline Sirvientes adultos/esclavos & & \\
\hline Mujeres empleadas [hired women] & $73^{(\mathrm{b})}$ & $16^{(\mathrm{c})}$ \\
\hline $\begin{array}{l}\text { Mujeres bajo contratos forzosos } \\
\text { [indentured] }\end{array}$ & $\mid------$ & $3^{(\mathrm{c})}$ \\
\hline Hombres empleados [hired men] & 129 & $17^{(\mathrm{c})}$ \\
\hline $\begin{array}{l}\text { Hombres bajo contratos } \\
\text { forzosos [indentured] }\end{array}$ & 15 & $24^{(\mathrm{c})}$ \\
\hline Mujeres esclavizadas & $\mid-----$ & 107 \\
\hline Hombres esclavizados & $\mid-----$ & 91 \\
\hline Dependientes legales totales & 4283 & 1893 \\
\hline Población total & 6260 & 2354 \\
\hline \% Dependientes legales & 68,4 & 80,4 \\
\hline Población adulta & 3281 & 1011 \\
\hline
\end{tabular}




\begin{tabular}{|l|l|l|}
\hline \% Dependientes legales. & 39,8 & 54,4 \\
\hline
\end{tabular}

a) Basado en el supuesto de que las esposas en Inglaterra conformaban un $60 \%$ de la población femenina libre adulta y en las colonias un 75\%. Para ambos lugares ver Daniel Scott Smith, "Female Householding in Late 18th-Century America: A Porto-Classical Overview," Table 2 (paper delivered at Lois Green Carr: The Chesapeake and Beyond conference, University of Maryland, May 23, 1992). b) Las mujeres sirvientes adultas y libres en Inglaterra se estiman en un $4 \%$ del total de mujeres adultas, correspondiendo con las figuras que Peter H. Lindert cita antes y después de 1755; ver Lindert, "English Occupations, 1670-1811" Journal of Economic History, 40 (1980), 702-04 .

c) El desglose en edad y sexo de los sirvientes empleados y contratados están basados en "The population of Maryland 1755," Gentleman's Magazine, 34 (1764), y David Galenson, White servitude in Colonial America (Cambridge, 1981), 25-27.

Fuentes: Alice Hanson Jones, American Colonial Wealth: Documents and Methods, $2 d$ ed., 3 vols. (New York, 1977) III, 1787, y Lindert, "English Occupations, 1670-1811", 702-04.

La población mayormente afectada por la expansión de la autoridad doméstica de los euroamericanos fueron los africanos transportados cruzando el Atlántico durante los siglos XVII y XVIII y los descendientes de estos inmigrantes forzados. Para el momento de la guerra americana por la independencia, los afroamericanos y aquellos de ascendencia racial mezclada componían el 20 por ciento de la población de las colonias británicas a nivel continental y alrededor del 90 por ciento de la población de las Indias Británicas Occidentales [que comprendían a las islas Bahamas, Barbados, Jamaica, Trinidad y Tobago, Guyana Británica y Honduras Británica]. Los africanos también componían la mayoría de la población en las posesiones americanas de los franceses, los holandeses y los portugueses. En las trece colonias, 96 por ciento de los afroamericanos eran propiedad esclava, miembros permanentes del hogar de su amo, y no de un hogar que ellos pudieran erigir, y sus hogares carecían de reconocimiento legal, sin importar que estos estuvieran organizados en forma conyugalmente patrilineal como en las sociedades anglo, o en cualquier otra forma.${ }^{59} \mathrm{Ni}$ la legislación en torno al matrimonio ni las leyes que versaban sobre los bastardos y la fornicación que las autoridades coloniales respaldaban de manera tan entusiasta tenían relevancia sobre la población esclava. Los poderes que se concedían a los hombres como esposos o padres no aplicaban a los afroamericanos. Tampoco, según ciertas leyes coloniales, podría algún "negro, mulato o indio," libre o esclavo, ser amo de un sirviente blanco contratado. ${ }^{60}$ Existe cierta evidencia de que los grupos culturales africanos transportados a las Américas tenían conceptos sobre el gobierno de la familia tan diferentes del concepto anglo como aquellos de las sociedades nativas americanas. Los poderes del linaje y los lazos madre-hijo pueden haber tenido una posición privilegiada para los africanos que era desconocida para los angloamericanos. ${ }^{61}$ Pero cualquiera hayan sido sus preferencias en la organización de la familia, la sociedad británica colonial no les otorgó reconocimiento alguno.

La autoridad del jefe de hogar blanco también se expandió como resultado de los cambios hechos por los colonos en las leyes que regían la servidumbre. Los ingleses en Inglaterra básicamente restringieron los lazos de servidumbre forzosa al aprendizaje de los menores. Una de las formas que adoptó la servidumbre en Inglaterra fue el estatus privilegiado que requería al padre pagar a un maestro para entrenar a su hijo en un oficio para que luego, como un adulto, el hijo pudiera calificar a ser miembro del gremio de dicho oficio. La otra forma, el "aprendizaje parroquial," colocaba a niños indigentes en hogares para que trabajaran sin salario hasta la adultez (21 años para los hombres y 18 para las mujeres). Así, las autoridades inglesas no forzaron a los adultos a 
servir dentro de Inglaterra. Sin embargo, en la América británica los adultos servían forzosamente sin salario en lapsos de 4 o 5 años y sin ninguna promesa de formación para un oficio [lo que se conocía como indentured servitude o servidumbre forzosa]. En Inglaterra, el servicio de los adultos como el de los jóvenes consistía en pagos anuales. La distinción legal entre mano de obra blanca "libre" o empleada [hired] y aquella "no libre" o bajo contratos forzosos [indenture] ha sido analizada detenidamente..$^{62}$ Lo que ha llamado la atención a muchos historiadores es cuán poco libres eran las disposiciones inglesas sobre el trabajo libre. Robert Steinfeld ha incluso argumentado que "la ley colonial de servidumbre forzosa solo difiere modestamente en sus fundamentos de la ley que gobernó el servicio en los inicios de la Inglaterra moderna," aunque sí afirma que la práctica era más dura. ${ }^{63}$ Dado que los sirvientes bajo contrato forzoso eran propiedad mueble de sus amos, sus contratos podían ser vendidos o transferidos, y los adultos podrían ser forzados a servir sin paga. Así, la postura de Steinfeld parece muy extrema. Algo que nunca ha sido adecuadamente explicado es por qué, en la América colonial, el trabajador fue quien cubrió el costo del transporte a las colonias, mientras en la mayoría de otros periodos y lugares este recayó en el empleador que necesitaba la fuerza de trabajo o en el gobierno que alentaba la inmigración o emigración. Los amos coloniales tenían mucho mayor poder sobre el trabajo y la disciplina de los sirvientes forzosos [indentured servants] que sobre los sirvientes libremente empleados [hired servants]. Los comportamientos que para los sirvientes empleados en Inglaterra no aparejaban castigo o, en el peor de los casos, el despido, resultó en azotes o en la extensión del plazo del servicio para aquellos bajo servidumbre forzosa en América.

Al enfatizar la posición de desventaja de los sirvientes forzosos, no estoy denegando el punto principal de Steinfeld: ser un sirviente empleado [hired servant] conllevaba la dependencia legal. Aquellos con un plazo de trabajo de un año o menos debían cumplir su plazo de servicio o arriesgaban una acción criminal. ${ }^{64} \mathrm{Un}$ sirviente que se retiraba no tenía derecho a exigir los salarios no pagados que hubiese obtenido hasta ese momento, y los tribunales no siempre reconocían el reclamo que un sirviente hubiese hecho por salarios adeudados, incluso si el amo hubiese violado el contrato abusando físicamente de él, o rechazando el tratamiento para la enfermedad del sirviente. Después del cumplimiento del servicio, el sirviente necesitaba obtener un testimonio por parte del amo para poder viajar y ocupar otra posición. El amo y no el sirviente era quien podía demandar ante el tribunal por injurias que este último hubiese sufrido en el trabajo o, en el caso de las sirvientes mujeres, por haber sido seducidas.

Otra razón por la que el vínculo colonial de servidumbre creció es que los gobiernos lo usaron como un sustituto para la disciplina correccional y la beneficencia social. Un año podía ser agregado al plazo de servicio de un sirviente forzoso que hubiese atacado a un amo en Virginia, y la misma sanción aplicaba a un sirviente que se hubiese casado sin el consentimiento de su amo en Carolina del Norte. Huir implicaba servicio extra durante un plazo igual o doble del tiempo que se hubiese fugado en Carolina del Norte o igual al costo de captura y tiempo perdido en Virginia. Cualquier conducta díscola también significaba tiempo extra de trabajo. Las mujeres sirvientes en Virginia que quedaran embarazadas servían un año extra si el padre era euroamericano y dos años extra si era afroamericano. El niño mulato o el hijo blanco de una mujer convicta, además, servía al amo de la madre hasta los 28 o 21 años respectivamente. En casi cada colonia, las sirvientas forzosas veían su servicio extendido por dar a luz un bastardo. Aunque los sirvientes podían quejarse por maltrato ante cualquier juez de paz, en un lugar como Carolina del Norte el entusiasmo por dicha acción legal se evaporaba al 
saber que un resultado desfavorable conllevaba un servicio extra por el doble del tiempo ocupado en el procesamiento del caso, y que un resultado favorable en el juicio significaba, en última instancia, que el sirviente sería vendido, y que el amo obtendría los ingresos de dicha venta. ${ }^{65} \mathrm{~A}$ diferencia de la situación en Inglaterra, donde los amos recibían pocos beneficios materiales por reportar una infracción cometida por un sirviente, los amos coloniales, desesperados por obtener mano de obra, tenían el incentivo de exprimir más tiempo de trabajo de sus trabajadores [denunciando a sus sirvientes para extender el plazo de servicio forzoso].

Incluso en las colonias que no se asociaban normalmente con el tráfico de sirvientes forzosos, las autoridades usaron el vínculo de servidumbre en los hogares para lidiar con los problemas criminales y de beneficencia. En Massachusetts, selectmen o vigilantes de los pobres podían forzar a una mujer soltera a la servidumbre por hasta cinco años por los gastos asociados al parto o al soporte económico de su hijo. Los párrocos ingleses absorbieron el costo de los partos como un caso de "impotencia casual", y la pena máxima por colocar a la parroquia a cargo de los gastos de mantener a un niño hasta los 7 años era de un año en la casa correccional. En colonias como Virginia, las autoridades no siempre esperaban la edad de 7 años para obligar a los niños pobres a servir a otro. ${ }^{66}$ Los manuales de la justicia de paz inglesa se referían a los pobres como aquellos que "eran viejos y decrépitos, inhabilitados para trabajar, viudas pobres, niños sin padres e inquilinos llevados a la pobreza (...) por desgracia". En el manual de la Massachusetts colonial, la redacción era mucho más restringida. Este especificaba que los selectmen y los vigilantes de los pobres se hicieran cargo de las personas "impotentes y perturbadas". Los selectmen de Massachusetts tenían incluso la autoridad para colocar en servicio forzoso a personas con una propiedad raíz, pero que consideraban ociosas y disolutas, entregando el producto de su trabajo a su familia o sus parientes. ${ }^{67}$

[La servidumbre también reemplazaba la función de beneficencia pública que de otro modo hubiese recaído en el estado o en la iglesia]. Los sirvientes empleados, sirvientes forzosos y esclavos que sufrieran enfermedades o discapacidades por una herida o por la avanzada edad tenían que ser mantenidos por sus amos por lo que durara el plazo de su servicio, lo que significaba, en el caso de los esclavos, de por vida. Dado que esa porción de la población realizaba la parte más agotadora del trabajo físico, era también la que tenía mayores probabilidades de ser herida. Con esta gran proporción de población trabajadora que caía en la categoría de servidumbre y quedaba bajo la responsabilidad de sus amos, era posible disminuir la responsabilidad pública por los incapacitados, los así llamados "pobres merecedores".

Casi todas las colonias del norte también utilizaron la servidumbre forzosa como una opción para los acreedores, particularmente aquellos que tenían un crédito respecto de personas que no tuvieran dependientes. En Pennsylvania, los deudores solteros bajo los 53 años podían ser atados en servidumbre hasta por 7 años, y los morosos casados podían ser forzados a servir por 5 años ${ }^{68}$ Ya sea que se considere esta práctica como algo preferible a la prisión, o bien como una táctica para exprimir la última onza de trabajo de los pequeños deudores pobres (quienes, en las colonias que reconocían la prisión por deudas, podían hacer un juramento de pobreza y ganar su libertad), esto en cualquier caso incrementó el dominio del jefe del hogar.

51 El estado subdesarrollado de las instituciones gubernamentales acrecentó la autoridad del jefe de hogar en otras formas. Ninguna de las colonias adoptó alguna de las medidas, populares entre la clase propietaria en Inglaterra a fines del siglo XVII y el 
siglo XVIII, que buscaban contrarrestar la tendencia individualista de la cabecera del hogar. Los fideicomisos familiares [strict family settlement], los fideicomisos matrimoniales [marriage settlements], y la Ley en contra de los Matrimonios Clandestinos de 1753, todo esto les recordaba a los jefes de hogar o potenciales jefes de hogar de sus obligaciones con el linaje. El fortalecimiento de estos acuerdos legales, sin embargo, dependían de las burocracias tanto judiciales como eclesiásticas que nunca se materializaron en la América colonial.

El fideicomiso familiar [strict family settlement] protegía el patrilinaje de la elite británica. Bajo estos arreglos, los herederos recibían solo el uso vitalicio de una propiedad inmueble, y el efecto de esto era perder su habilidad para enajenar la mayor parte de la riqueza que habían heredado. En su lugar, la mayor parte de las propiedades inmuebles descendían a un heredero varón sin desheredar completamente a las hijas, hijos menores y viudas. Los jefes de hogar como individuos perdían cierta flexibilidad y poder personal, pero el primogénito comúnmente ganaba más recursos de por vida, porque estos acuerdos a menudo otorgaban menores dotes a las viudas y encogían la porción de las herederas. ${ }^{69} \mathrm{La}$ idea básica, era temperar el individualismo inherente en la libertad testamentaria otorgada en la era Tudor-Estuardo. Nada comparable emergió en las Trece Colonias. El uso que se dio en Virginia a las restricciones hereditarias [entail] fue la que más se acercó al fideicomiso familiar, pero fue comprendida como mucho menos abarcadora que dicho sistema, fue protegida de manera desigual en los tribunales y gozó de poca popularidad fuera de Chesapeake. ${ }^{70}$

Para las mujeres casadas y su linaje, la jurisprudencia de equidad [que corregía las tendencias más estrictas y formalistas del common law] proveyó de medios para salvaguardar su riqueza a través de acuerdos prenupciales, los cuales crearon patrimonios separados supervisados por fideicomisarios. A juzgar por los modestos pero firmes niveles de litigación en las cortes de cancillería [que fallaban de acuerdo a la equidad], las mujeres inglesas y sus familias hicieron uso de estas herramientas, ${ }^{71}$ aunque las opiniones difieren sobre cuán efectivas eran en proteger a las mujeres y darles cierta autonomía en materias de propiedad..$^{72}$ Cualquiera sea el caso, durante los inicios de la era moderna tanto los fideicomisos familiares como los procedimientos ante la cancillería que hacían cumplir la separación de bienes y los fideicomisos matrimoniales se restringían a los ricos, y poco hicieron por minimizar la autoridad de la gran mayoría de los jefes de hogar. En la generalidad de la población, quizás entre un 1 y un 2 por ciento de las mujeres tomaron alguna forma de disposición para establecer la separación de bienes, y otro 2 a 3 por ciento hicieron que sus esposos, antes del matrimonio o durante el mismo, apartaran una porción de sus propiedades para asegurarse de que no serían dejadas en la indigencia. ${ }^{73}$ Por otro lado, considerando la proporción del total de las fortunas personales que eran afectadas por estos mecanismos, estos dispositivos no eran nada de triviales. En las colonias, la lenta implementación de la jurisprudencia de equidad significó que las mujeres casadas propietarias tenían pocos recursos legales si ellas o sus parientes hombres buscaban proteger su riqueza de un esposo depredador. Las colonias disidentes rechazaron reconocer los fideicomisos matrimoniales por la asociación histórica [de las cortes de cancillería] con las cortes "despóticas" de los Tudor-Estuardo, y por su potencial en debilitar la unidad conyugal. La mayor parte de las otras colonias establecieron cierta forma de corte de cancillería que dispensaba la justicia de equidad, pero los 
fideicomisos matrimoniales apenas protegieron una cantidad inconsecuente de riqueza.

La ausencia de una burocracia eclesiástica en las colonias también previno la implementación de la ley del Parlamento Británico de 1753 en contra de los matrimonios clandestinos. Esta medida, que anulaba los matrimonios contraídos por menores sin el consentimiento de sus padres, subrayaba la obligación que tenían los jóvenes para con ambos linajes y respecto del jefe de hogar. Las legislaturas coloniales no emularon a la madre patria aprobando leyes similares. E, incluso si lo hubieran hecho, las leyes hubieran sido imposibles de hacer cumplir, dada la falta de una iglesia establecida y aceptada por todas las colonias, o de un sistema de registro centralizado de los matrimonios celebrados. A este respecto, la expansión de la autoridad del jefe de hogar a expensas del poder del gobierno civil terminó por limitar el poder del jefe de hogar para controlar a sus hijas e hijos.

\section{¿Una revolución americana en el gobierno familiar?}

Mientras las colonias formaron parte de la corona británica, los poderes patriarcales del jefe de hogar, incluso en su forma expandida, parecían estar en armonía con el resto de la estructura política. Las imágenes del rey como el padre de sus subordinados y los padres como jefes de pequeños commonwealths se apoyaban la una a la otra. Una interpretación común es que la Independencia llevó a su fin no solo el poder monárquico, sino también el poder patriarcal en el hogar, generando una nueva familia afectiva. ${ }^{75}$ Los estudios se han centrado mayormente en la relación entre padre e hijo varón o entre padre e hijos $\mathrm{y}$, usando primordialmente material literario, apuntan a una menor formalidad de las relaciones y menor control sobre la ocupación y el matrimonio. Un historiador literario ve una nueva liberación sexual para las mujeres emergiendo en el periodo revolucionario, una tendencia que luego fue apagada por el victorianismo. ${ }^{76}$ Otro trabajo sostiene que el estatus de las esposas, así como el de las hijas cambió. De manera simbólica, madres y esposas ganaron un nuevo respeto en la república por su rol como educadoras y preceptoras morales, y su nueva situación llevó a la creación de una cultura política separada para las mujeres. Legalmente, la desaparición de la primogenitura otorgó a los hijos menores y a todas las hijas los mismos derechos legales de herencia si el padre moría abintestato. La ruptura del contrato social con el rey, tal y como fue justificado en la Declaración de Independencia, permitió asimismo la ruptura del contrato matrimonial a través de procedimientos de divorcio. ${ }^{77}$ Los estados del norte aprobaron leyes de emancipación gradual o abolieron la esclavitud, y una porción cada vez menor de los trabajadores servían bajo la categoría de "sirviente forzoso".

En cambio, la politóloga Carole Pateman ha argumentado que las revoluciones republicanas de fines del siglo XVIII establecieron nada más que un patriarcado fraternal de hombres blancos y adultos que repartieron su poder más ecuánimemente entre ellos mismos, pero hicieron poco por dar igualdad a otros. ${ }^{78}$ En efecto, los grandes debates del periodo involucraron el sufragio universal para los hombres blancos adultos, no los derechos sobre los miembros dependientes del hogar. Dados los límites a la igualdad, se hace necesario distinguir la estructura autoritaria que existía dentro del hogar de esa otra estructura política. No es ningún accidente que los escritores de inicios del periodo nacional dedicaran una atención considerable a contrastar las 
esferas de lo público y lo familiar. La esfera pública, donde los hombres blancos adultos y libres perseguían sus intereses políticos y económicos como jurídicamente iguales, fue retratada como un mundo de competencia despiadada. La esfera doméstica, donde los hombres blancos adultos y libres no tenían que tratar con iguales jurídicos, fue representada como el lugar de refugio, afecto y amor. ${ }^{79}$

Algunos historiadores llegan a argumentar que la Revolución Americana tuvo poco efecto en la dependencia de la mujer adulta. Joan Hoff observa, literalmente, ninguna mejora en la posición legal de las mujeres después de la Revolución, y muestra que incluso por parte de las mujeres educadas había aversión en argumentar a favor del derrocamiento del coverture. ${ }^{80}$ Linda K. Kerber caracteriza el periodo que sigue a la Revolución como "termidoriano". Esta autora escribe que "los hombres que apoyaron la Revolución, al término de este periodo buscaron desactivar las memorias de violencia revolucionaria (...) para constreñir la renegociación de los roles de género". ${ }^{81}$ Mis propias investigaciones sobre el control de las mujeres sobre el capital revelan que ninguno de estos cambios legales que afectaban a las mujeres blancas en los albores de la república alteraron notablemente la cuota de riqueza personal de las mujeres. ${ }^{82}$ Puede ser que ciertos cambios en los poderes informales dentro del hogar que se vieron reflejados en los diarios íntimos del periodo post-Revolucionario, así como en la proliferación de la literatura escrita por y para mujeres, hayan contribuido a la aparición de grupos defensores de los derechos de las mujeres después de 1830. Sin embargo, las innovaciones respecto de la herencia, el divorcio y la separación de bienes, que han sido a veces citadas como productoras de los mayores cambios en el estatus de las mujeres de la generación postrevolucionaria no parecen haber afectado a muchas de ellas.

La abolición de la primogenitura les dio a las hijas una mayor porción de los bienes intestados, pero como casi todas las hijas se casaban, el control sobre su herencia recayó en sus esposos. Además, los padres podían negarse a esta norma simplemente otorgando un testamento, algo que casi todos los hombres con cantidades considerables de propiedad hicieron de todos modos.

La legislación sobre el divorcio con disolución de vínculo fue aprobada en todos los estados menos en Carolina del Sur durante los inicios del periodo nacional y, en teoría, debiera haber inaugurado un cambio sustancial en los poderes del esposo sobre las esposas. Por primera vez en muchas jurisdicciones, una mujer tenía medios legales para terminar el matrimonio y el coverture antes de su propia muerte o la de su esposo. Dado que el cálculo del número de divorcios en la mayoría de los estados empieza en cero, los índices de incremento doblaron o incluso se triplicaron durante este período. Pero una debiera preguntarse cuál es el significado real que tiene un índice de divorcios de 0,03 por 1000 habitantes, aquel estimado por Martin Schultz para los Estados Unidos en $1800{ }^{83}$ Significa 159 divorcios al año para 5,3 millones de personas, esto es, menos de un divorcio cada dos días para la nación completa. Para los estándares actuales, esta carga de trabajo pudo ser tratada por dos abogados y aún así dejarles tiempo para realizar más labores remuneradas. Algunos estados pequeños tuvieron índices mucho mayores, pero casi todos los estados más densamente poblados-Virginia, Pennsylvania, Nueva York y Massachusetts-empujaron el promedio a la baja. ${ }^{84}$ La sospecha es que los números abultados en lugares como Connecticut, Vermont o Rhode Island se debía a esposas desesperadas de otras jurisdicciones que acudían a estos estados buscando resolver su caso. ${ }^{85}$ Los estados mantuvieron los índices de divorcios en niveles 
insignificantes por una variedad de medios: entregándole solo a la legislatura o a la corte suprema del estado la competencia para declarar el divorcio (en los estados sureños), renunciando a incluir la crueldad como causal para un divorcio absoluto (Massachusetts y Nueva York), denegando la mayoría de las peticiones de divorcio (Pennsylvania), otorgando la custodia de los hijos automáticamente al padre, y rehusándose a aplicar las normas sobre pensión alimenticia o la división equitativa de la propiedad (en todos los estados). ${ }^{86}$ Consecuentemente, los divorcios del inicio del periodo nacional representaron una disminución de los poderes patriarcales del esposo solamente en un grado mínimo.

60 Algunas de las causales de divorcio-por ejemplo, bigamia, impotencia y consanguinidad-no se desviaban dramáticamente de la tradición. Por siglos habían sido los principales medios empleados por los europeos para terminar matrimonios. Además de estas causales, que raramente se usaban en Estados Unidos, los peticionarios ante tribunales locales tenían que probar la deserción o el adulterio. ${ }^{87}$ Dependiendo del estado, las mujeres interpusieron entre dos tercios al $80 \%$ de las demandas. En los casos en que habían desarrollado su propio medio de sustento o habían heredado la propiedad de sus familiares, las mujeres se beneficiaron con el sistema de divorcio, no viéndose ya obstaculizadas por el estatus de "feme covert" como dependientes legales de un marido que las había abandonado o vivía por separado con otra mujer. El punto es, sin embargo, que por esa deserción el marido ya había renunciado a la autoridad y la manutención del hogar, y los tribunales simplemente formalizaban esta abdicación. Pero para un quinto a un tercio de las mujeres que se divorciaban de sus esposos, usualmente por adulterio, las consecuencias eran muy diferentes. Perdían todos los reclamos de manutención y propiedad, incluidos los derechos de dote, y la custodia de sus hijos. La vieja prohibición colonial del divorcio había negado a un cornudo la opción de deshacerse de su esposa y sin embargo conservar su propiedad. Esta restricción a librarse de las esposas había sido uno de los frenos tradicionales a la autoridad patriarcal exigidos por las iglesias cristianas. Sin embargo, bajo las nuevas leyes republicanas de divorcio, los maridos recuperaron ese poder perdido hace mucho tiempo. No es sorprendente que los primeros divorcios legislativos otorgados en Maryland y Virginia involucraran a esposas adúlteras que dieron a luz a niños mulatos. 88

61 Las oportunidades para separaciones legales (divorcios sin disolución de vínculo o demandas para obtener la manutención separada) por crueldad o abuso habían estado disponibles en casi todas las jurisdicciones antes de la Revolución. Después de la Revolución, los tribunales de cancillería, que en varios estados manejaron los arreglos patrimoniales, se volvieron más reacios a validar las separaciones mutuamente acordadas entre esposo y esposa. ${ }^{89}$ Pero si una esposa podía probar la mala conducta de su esposo, podía obtener la pensión alimenticia. El monto inicial del beneficio y su continuación dependía de su buena conducta, lo que generalmente significaba celibato. Muchos esposos no pudieron o no quisieron pagar. De acuerdo a un juez de apelaciones de Massachusetts en la "mayoría de las instancias" ese fue el caso en su estado. ${ }^{90} \mathrm{Se}$ pueden invocar muchos ejemplos de lo que Michael Grossberg ha calificado de "patriarcado judicial". ${ }^{11}$ Sin embargo, la impresión que se obtiene al leer estas apelaciones es que los jueces evitaban todo lo posible ejercer sus deberes patriarcales. Sólo porque las mujeres y sus parientes persistieron en interponer recursos es que los jueces terminaron por intervenir. Los tribunales de cancillería o aquellos tribunales del common law que tenían jurisdicción de equidad también lidiaron con los casos relativos 
a las separaciones de bienes que protegían la propiedad que las mujeres aportaban al matrimonio. Existe algo de evidencia de que la incidencia de los patrimonios separados incrementó con el tiempo, pero el período documentado es posterior a $1820 .{ }^{92}$

Ha sido ampliamente sostenida la creencia de que la era revolucionaria tuvo un efecto fulminante en la autoridad del padre sobre sus hijos. ${ }^{93}$ Las nociones sobre las tendencias antipatriarcales del republicanismo se fusionan con los argumentos sobre la modernización de las familias para producir una gran piedra teórica de afectividad intergeneracional, la que parece rodar por una colina entre 1750 y 1850, aplastando consigo el yugo paternal así como el control patriarcal sobre el matrimonio y las ocupaciones de los hijos. Sin embargo, la noción de un cambio que se extiende por un siglo de duración hace difícil identificar qué cambios podrían estar relacionados con cierta plausibilidad a la generación revolucionaria. Además, muy poca de la evidencia reunida se relaciona con el tema de este artículo-los cambios en la autoridad legal ejercida por los jefes de hogar sobre sus dependientes. La escasez de investigación hace difícil llegar a cualquier conclusión firme sobre tendencias. Holly Brewer atribuye el cambio más significativo en el estatus legal a las ideas de la Ilustración sobre la inocencia de los niños. Estas ideas, sostiene, hicieron a los tribunales menos accesibles para las víctimas jóvenes, debido a la suposición de que aún no alcanzaban la razón. ${ }^{94}$ Su argumento implicaba que los niños tenían menos, no más, capacidad para contrarrestar a la autoridad legal de su jefe de hogar. Desde una perspectiva comparada, se muestra que los padres ejercieron poco control sobre los matrimonios de sus hijos, sin embargo, esto parece una consecuencia de lo que las autoridades angloamericanas dejaron de hacer, y no tanto de lo que hicieron. Tampoco está bien documentada la conexión entre la Revolución y los matrimonios arreglados por los mismos contrayentes y no por sus padres.

63 Pero ¿Qué hay de la esclavitud? Seguramente allí el periodo revolucionario marca una importante desviación respecto del poder del jefe de familia en comparación con el periodo previo. La parte norte de Estados Unidos, desde los inicios del periodo nacional, se embarcó en una política de emancipación gradual que revirtió la tendencia de un siglo de duración de crecimiento de la proporción de población esclavizada y del poder de los amos. ${ }^{95}$ La abolición de la esclavitud en el Norte fue una admisión de que la expansión de la autoridad doméstica involucrada en la relación amo-esclavo había sido un giro equivocado, y los estados aprobaron una legislación que transformaba a los esclavos jóvenes en sirvientes que, según se esperaba, podrían emigrar a otras jurisdicciones o incluso retornar a África.

Sin embargo es importante recordar que sólo el $10 \%$ de la población afroamericana vivía en los estados del norte. Algo absolutamente distinto ocurrió en los estados del sur donde vivía el $90 \%$ restante. Con proporciones muchos más altas de afroamericanos entre ellos, y una continua necesidad de mano de obra para producir productos de plantación, la población angloamericana de los estados del sur vio pocas posibilidades de liberarse de la esclavitud o de los afroamericanos. Después de un breve período de emancipación post revolucionario, los sureños volvieron a una gran importación de africanos antes de que la prohibición de 1808 entrara en vigencia. Internamente, sus legislaturas aprobaron leyes que hacían cada vez más difícil emancipar a personas esclavizadas o que los esclavos emancipados cruzaran las fronteras estatales. ${ }^{96}$ Esta situación en el Sur, combinada con la incapacidad de los norteños de abolir la servidumbre forzosa o de cambiar sustancialmente las leyes sobre amo y sirviente, 
sugiere un compromiso continuo con la gobernanza doméstica tradicional, a pesar de que las expansiones más radicales de esta gobernanza durante el período colonial fueron rechazadas por los estados del norte. ${ }^{97} \mathrm{En}$ los estados del sur, el apoyo para esta expansión se solidificó a medida que los propietarios de esclavos los trasladaron hacia las ricas tierras algodoneras del Oeste. ${ }^{98}$

Desde el punto de vista de 1815-la fecha de manual que marca el fin del temprano período nacional-nadie habría predicho el derrumbamiento del tradicional gobierno familiar. Sin embargo, a pesar de lo intelectualmente inquietante que haya sido la disyuntiva entre la ideología revolucionaria y el estatus de las personas dependientes, no se materializó ningún movimiento significativo para abolir la esclavitud, la servidumbre, la coverture de las esposas y el trabajo infantil durante este período. Unos cincuenta años después, tras la Guerra Civil (1861 a 1865), la situación había cambiado radicalmente. La aparcería remplazó a la esclavitud, y la servidumbre forzosa euroamericana había dado paso a los contratos forzosos de asiáticos fuera del ámbito familiar. Los sirvientes empleados se transformaron en mano de obra libre, las leyes sobre la propiedad de la mujer casada tuvieron como resultado la desaparición de la coverture, las leyes de divorcio permitieron a las mujeres salir de los matrimonios incluso si sus maridos se hubiesen negado, y en el caso de lo hijos, el derecho del padre sobre su trabajo se había visto afectado por las leyes de educación obligatoria y legislación laboral protectora. ¿Qué había pasado?

\section{Interrogando al sospechoso de siempre: El mercado}

Probablemente ningún campo de la historia haya sido tan influenciado por la teoría de la modernización como la historia de la familia. Un ejemplo típico de la teoría de la modernización es la siguiente explicación:
A finales del siglo XVIII y comienzo del siglo XIX se produjo una redefinición fundamental de los límites de las esferas privadas y públicas. A principios del siglo XVII las funciones de las familias eran amplias y difusas. La familia era la unidad fundamental de la sociedad. Educaba a los niños; se preocupaba de los ancianos y de los enfermos; transfería propiedades y habilidades a la siguiente generación; y lo más importante, era el centro económico de producción. Para principios del siglo XIX, las instituciones no familiares realizaron la mayoría de estas funciones. Los principales roles de la familia de clase media eran proporcionar apoyo emocional y afecto, y contribuir a la socialización de los niños. ${ }^{99}$

La esencia de buena parte de la investigación de los últimos veinte años sobre la historia de las mujeres, la historia laboral y la esclavitud sugiere que el análisis mencionado anteriormente confunde las actividades de la familia angloamericana con la autoridad del jefe de familia como padre, esposo y amo. A principios del siglo XIX ¿Acaso la familia había pasado de ser pública a privada o bien los poderes "públicos" del padre se estaban erosionando? Todos los demás miembros del hogar, como dependientes, siempre fueron tan privados y tan carentes de posición pública como podía ser. Colocar la redefinición fundamental a finales del siglo XVIII y principios del siglo XIX parece prematuro, considerando que durante el curso del período colonial la autoridad de los jefes de familia angloamericanos se incrementó, y esto cambió muy poco para la mayoría de los dependientes durante la era nacional temprana. Además, antes de que las instituciones no familiares llegaran a realizar muchas de esas funciones, tuvieron que ocurrir cambios legales básicos en lo que respecta al estatus de 
las personas dependientes. Estos cambios fueron controversiales en el mejor de los casos, y devastadoramente violentos en los peores. Sospecho que la desdeñosa actitud hacia la historia de la familia que se encuentra hoy en día entre algunos historiadores está arraigada en lo que ellos creen es un oscurecimiento de estas relaciones de poder y conflictos.

En segundo lugar $¿$ Era realmente el caso de que a principios del siglo XIX el hogar o incluso la familia de clase media ya no servía como centro económico de producción y que las instituciones no familiares educaban a los niños, transferían propiedades y habilidades a la próxima generación y cuidaban de ancianos y enfermos? Los entusiastas de la modernización no son los únicos en plantear este gran argumento de transformación y situarlo tan tempranamente; su perspectiva es compartida por aquellos que trabajan dentro de los marcos de los conflictos de clase. Para ellos, el cambio del hogar está menos asociado con la industrialización que con la revolución del mercado, y algunos rastrean este fenómeno ya desde la década de 1750. Las demandas del mercado por una fuerza laboral móvil rompieron las dependencias del hogar y liberaron a la mano de obra para contratar. Este desarrollo es central en la mayoría de las explicaciones de por qué desapareció la servidumbre, los sirvientes forzosos y el aprendizaje disminuyeron, y por qué el Norte finalmente forzó al fin de la esclavitud. También se utiliza para explicar la disminución de la autoridad patriarcal sobre los hijos y las esposas. Como escribe Sean Wilentz, "el declive del hogar como lugar de producción condujo directamente al crecimiento de la impersonalidad en la esfera económica; los jefes de hogar, en lugar de dirigir empresas familiares o tiendas pequeñas, con frecuencia tenían que encontrar formas de reclutar y disciplinar a una fuerza laboral asalariada". Del mismo modo "la comercialización del campo y la ciudad removió a las mujeres de la producción de bienes, incluidos los bienes para estricto uso familiar... Hacia 1850, un nuevo estándar romántico de derechos y responsabilidades para la familia de clase media había remplazado al más severo régimen patriarcal del siglo XVIII... mientras restringía el lugar de las mujeres al hogar, como esposas, madres y guardianas domésticas". ${ }^{100}$

Sin embargo, ¿Cómo puede la caída del hogar como el sitio de producción económica explicar la caída de la gobernanza doméstica tradicional, cuando la desintegración de la servidumbre, el derecho sobre amos y sirvientes, la esclavitud y la coverture procedieron a un ritmo más rápido que la desaparición del hogar como sitio productivo? De acuerdo, sería difícil imaginar cómo los grandes espacios de trabajo industrial y las burocracias corporativas, gubernamentales y profesionales pudieran haber funcionado bajo un sistema de gobernanza doméstica, pero esto difícilmente describe la situación laboral de la mayoría de las personas en los Estados Unidos en 1800 o 1830, incluso en 1865. Más mujeres y hombres trabajaban en la agricultura que en todos los demás sectores combinados hasta 1880 . No fue sino hasta 1840 que la proporción de población viviendo en lugares urbanos (pueblos con 2500 o más personas) excedió al nivel encontrado en las colonias en 1690, o a Inglaterra en el siglo XVI. Sólo en 1920 los habitantes urbanos alcanzaron la mayoría de la población. No fue sino hasta finales del siglo XIX que muchos establecimientos industriales incorporaron o emplearon a un gran número de trabajadores en un sitio. ¿Por qué los hogares no pudieron simplemente continuar expandiéndose en tamaño? La mayoría de los hombres jóvenes obtuvieron formación comercial, profesional y manual de un jefe de hogar en vez de una escuela. ¿Por qué la servidumbre forzosa y el derecho de los 
sirvientes abarcó a un número cada vez menor de estos jóvenes y cada vez más de entre ellos encontraban alojamiento en lugares distintos al hogar? ¿Por qué terminó la esclavitud? Ciertamente no fue porque menos empresas agrícolas estuvieran basadas en el sistema familiar.

El movimiento para liberar a las mujeres casadas de la coverture comenzó en la década de 1830, nuevamente, mucho antes de que el lugar de producción se hubiese desplazado de los hogares. Los académicos han tratado de rastrear la desintegración de la coverture a la expansión del mercado, pero la diversidad de explicaciones induce dolores de cabeza. Algunos conectan las leyes que reformaron la propiedad de la mujer casada con los esfuerzos para incrementar la velocidad y la eficiencia del mercado de tierras y habilitar a los acreedores a cobrar las deudas. Esta explicación es problemática, porque estas leyes no hicieron nada para remover las disposiciones de la dote, el usual culpable citado entre los intereses de los acreedores que consideraban los acuerdos de coverture como feudales. Más aún, los estados del sur, jurisdicciones que usualmente no se consideraban a la vanguardia de la revolución del mercado, aprobaron muchas de estas primeras leyes. Por esta razón, algunos investigadores han retratado estas leyes como intentos de proteger a la familia de la dureza del capitalismo, especialmente de la bancarrota, protegiendo los recursos que la esposa traía al matrimonio. También se ha argumentado que las esferas separadas del mundo del mercado de los hombres y el mundo familiar de las mujeres les dio a estas últimas mayor autoridad en el hogar y mayor legitimidad como administradoras de la propiedad que aportaban al fondo conyugal. Sin embargo, no se explica por qué, al estar más restringidas a espacios familiares, las mujeres habrían requerido mayor separación de bienes de su riqueza y salarios. Finalmente, se ha sugerido que el crecimiento de los activos financieros, una forma de bienes muebles, incentivó la aprobación de estas leyes porque, a diferencia de los bienes raíces, esa riqueza caía completamente en manos del esposo en el matrimonio. A pesar de todo, los bienes muebles, ya fueran activos financieros, efectivo, ganado, artículos del hogar o esclavos, habían sido siempre el componente principal de la herencia de una mujer: ¿Por qué su familia se habría preocupado tanto de la transferencia automática de estos bienes hacía el esposo en el período previo a la Guerra Civil, y no objetó antes de esta situación? ${ }^{101}$

71 Sólo en el caso de cambios en el control del jefe de hogar sobre el trabajo de los hijos, se puede ver una estrecha asociación con el crecimiento de las grandes empresas no domésticas, y en consecuencia, el cambio vino después que para otras categorías de dependientes. El impulso a la escolarización obligatoria y las restricciones al trabajo infantil hechas por profesionales y algunas organizaciones de trabajadores ocurrieron por primera vez en la década de 1830 cuando se expandió la contratación de niños en las fábricas del noreste, y se extendió por Estados Unidos junto a la propagación de empresas, fábricas y lugares de trabajo burocrático. Los líderes educacionales querían que los niños fuesen a la escuela, pero también "consideraban a las leyes que interferían con el control parental como antidemocráticas". ${ }^{102}$ Se sentían más cómodos identificando a los empleadores industriales como el problema. Sin embargo, hasta los años posteriores a la Guerra Civil se aprobó muy poca legislación significativa relativa al trabajo infantil. Muchos estados esperaron hasta principios del siglo XX antes de intervenir el control parental y a los empleadores industriales. ${ }^{103}$ Incluso hoy, la capacidad de los niños de desafiar la autoridad de los padres y tratar directamente con el estado es muy limitada. 
72 Las objeciones a los poderes del jefe de familia desde tan diversos segmentos de la sociedad como sirvientes, esclavos, y mujeres casadas no fueron un resultado o consecuencia de la remoción a gran escala del hogar como centro de producción, sino que precedieron a este proceso. ¿Por qué el trabajo tenía que ser "libre"? ¿Por qué las mujeres podían tener bienes "separados", hacer testamentos y alejarse de la autoridad de su esposo sin enviudar o ser abandonadas? El crecimiento de las estructuras corporativas, los gobiernos burocráticos, y los lugares de trabajo industriales pueden haber facilitado este desarrollo, pero su naciente estado alrededor de la década de 1860 sugiere un patrón de causalidad más complicado que lo que sugiere el modelo de la revolución del mercado. ¿Cómo, entonces, perdieron los jefe de hogar el control legal sobre sus dependientes adultos?

\section{Los peligros de un gobierno familiar sin linaje: Una comparación entre angloamérica y latinoamérica}

73 Sospecho que una de las principales razones del por qué los jefes de familia perdieron el control legal de sus dependientes adultos es porque tenían muy poco control sobre las decisiones de formación del hogar de sus dependientes pre-adultos, es decir, sus hijos e hijas adolescentes. Esta falta de control era un proceso bidireccional que hundía sus raíces en un lejano pasado. En efecto, la ley limitó severamente los reclamos formales que los hijos en edad laboral podrían hacer a sus padres. Muy probablemente, cualquier observador asiático contemporáneo de los derechos y obligaciones legalmente exigibles de los miembros de la familia angloamericana, habría concluido que existía un estado de anarquía en Estados Unidos. Este ambiente libre de linajes fue probablemente la esencia del juicio de Tocqueville "en América, la familia, en el sentido romano y aristocrático de la palabra, no existe". ${ }^{104}$ Sin embargo, no es necesario ir a Asia o Roma para darse cuenta cuán lejos se había desviado Estados Unidos. Solo mirar del otro lado de la frontera a los gobiernos familiares latinoamericanos permite un contraste suficiente.

74 El concepto de gobierno familiar patriarcal recibió mayor apoyo institucional en las áreas dominadas por las coronas española y portuguesa que en la América británica. Una larga tradición jurídica explicaba detalladamente la patria potestad, esto es, la autoridad de los padres, y esa autoridad era considerable. La retención de la autoridad legal del padre sobre sus hijos adultos hasta que se casaran o murieran era la diferencia más notable con la práctica anglosajona. ${ }^{105}$ Para encontrar cualquier disposición comparable a este tipo de minoría legal perpetua en la experiencia inglesa, uno debe regresar a Bracton a mediados del siglo XIII. ${ }^{106} \mathrm{El}$ jefe de familia, en el régimen de patria potestad, tenía más autoridad sobre sus hijos que su contraparte anglosajona, y también tenía más obligaciones. Un padre casi no tenía la capacidad de desheredar a sus hijos. Sólo podía legar como quisiera una pequeña parte de su patrimonio, que en México colonial alcanzaba usualmente un $20 \%$. También estaba obligado a pagar por adelantado algunas o todas las herencias de sus hijas en forma de dote. Cuando las parejas se casaban, los notarios redactaban una carta dotal, especificando la propiedad de la dote. El esposo administraba tanto la dote de su esposa como las arras-el regalo del marido a la mujer al momento del matrimonio-, pero no podía enajenarlos libremente, a diferencia de un esposo bajo el common law inglés. Además, toda la riqueza acumulada durante el matrimonio se volvía parte del patrimonio común, y las 
viudas tenían derecho a la mitad del mismo, bastante más que el tercio del ingreso de bienes inmuebles al cual tenían derecho sólo de por vida las viudas angloamericanas. Es interesante destacar que, en muchos de los territorios mexicanos conquistados por Estados Unidos a mediados del siglo XIX, los anglos tomaron prestado el concepto hispano de patrimonio común para mejorar la condición de las mujeres casadas y abordar el tema de la propiedad de las mujeres casadas en sus nuevas constituciones y códigos. ${ }^{107}$

En México, la preocupación era el linaje. Como en el caso del esposo, la mayoría del patrimonio de la mujer pasaba automáticamente a sus herederos al momento de su muerte. El matrimonio no borraba ni el nombre ni la propiedad del linaje de la esposa, y estas protecciones circunscribieron los poderes del esposo. La percepción de que una mujer llevaba con ella el honor de su linaje también pudo haber sido la lógica detrás del enclaustramiento de las mujeres solteras, en un grado no observado en Angloamérica.

El cristianismo, el derecho canónico, y la burocracia de la iglesia también limitaron el poder de los jefes de hogar en Hispanoamérica. Tal como en Inglaterra y Angloamérica, la iglesia enseñaba que un hombre sólo puede tener una esposa, y que los padres no deben interferir con los matrimonios legales de sus hijos. Pero, a diferencia de la mayoría de los países angloamericanos, la Iglesia Católica en lugares como México colonial tuvo un importante ejército de funcionarios para imponer sus enseñanzas sobre el matrimonio y el comportamiento moral. Hasta cierto punto, los procedimientos policiales y burocráticos pusieron tantos más obstáculos en el camino a la libertad conyugal que lo que lograron despejarlo. Sin embargo, un cambio significativo iniciado por la corona española a finales del siglo XVIII, sugiere que la iglesia llegó a ser vista, correcta o incorrectamente, como una amenaza a las ambiciones dinásticas de los linajes. En el mismo año que algunos colonos angloamericanos declararon la independencia de Gran Bretaña, la corona española emitió una Real Pragmática sobre el Matrimonio, que dos años después también se aplicó a Nueva España. Estas reformas borbónicas, a grandes rasgos, quitaron el matrimonio de las manos de la iglesia y lo pusieron en manos de la autoridad secular y del padre. Hijos e hijas, bajo pena de desheredación, tenían que obtener el consentimiento de sus padre para casarse hasta que cumplieran 25 años. ${ }^{108} \mathrm{La}$ evidencia existente sobre nupcialidad en Latinoamérica colonial sugiere una edad femenina promedio de matrimonio a los 17-19 años y, en el 90\% de los casos, antes de los 25 años. ${ }^{109}$ La mayoría de edad establecida en la Real Pragmática era, por tanto, muy restrictiva. Los padres podían alegar legítimamente la "notable desigualdad" entre una pareja como motivo para oponerse a una unión. Las madres no podían contrariar la opinión de sus esposos ni otorgar sus propias opiniones. Sólo si sus esposos morían adquirían las madres el derecho de aprobación. Después de 1803, los padres ya no debían citar una causa de oposición al matrimonio de sus hijos. ${ }^{110}$

¿Por qué las autoridades españolas intervinieron para reforzar el poder patriarcal sobre el matrimonio? El movimiento de la corona se ha visto como un esfuerzo de largo plazo por parte de los gobiernos seculares para reducir el poder de la Iglesia Católica. ${ }^{111}$ Esta rivalidad, sin embargo, no explica el momento del cambio. En España, durante este período, se produjeron matrimonios controvertidos entre la aristocracia ${ }^{112} \mathrm{y}$, dado que no era un período de particular vitalidad económica, las familias adineradas podrían estar preocupadas por la indiferencia que sus jóvenes exhibían respecto de las consideraciones dinásticas. En las Américas, sin embargo, en un lugar como México, el 
siglo XVIII no fue necesariamente una época de depresión económica. Más bien, el entusiasmo por la medida en el Nuevo Mundo ha sido explicado en base a un elemento racial. A medida que las castas, esto es los grupos de origen racial mixto, aumentaron en número, se incrementó la preocupación por preservar una élite "española". Aunque la mayoría de los casos sometidos a las cortes reales que involucraban disputas entre padres e hijos sobre matrimonios no citaban la diferencia racial como el principal obstáculo de la unión, el temor respecto de la pérdida de estatus, cualquiera fuera su fuente, concitaron apoyo para reforzar el control patriarcal sobre el matrimonio de los hijos. ${ }^{113}$

78 La preocupación por controlar la formación del hogar de los hijos en México colonial y en el resto de América dominada por España y Portugal es interesante, considerando las muy diferentes preocupaciones que existían en Angloamérica desde la época colonial hasta la primera mitad del siglo XIX. El principal camino con que el gobierno angloamericano fortaleció la autoridad patriarcal en el área de la formación del hogar fue en relación a los poderes de los amos, no el poder de los padres. El derecho angloamericano prohibió el matrimonio entre esclavos, favoreciendo a los amos por encima de los esposos y padres afroamericanos. La ley también obligó a los sirvientes forzosos que se casaban o tuvieran hijos a cumplir períodos más extensos de servicio. Las condiciones de empleo para los sirvientes también impidieron el matrimonio durante el periodo de servicio. Las colonias (y después los estados) también prohibieron los matrimonios interraciales, en lugar de dejar tales uniones a la discreción patriarcal como en América Latina.

Sin embargo, en lo que respecta a la concreción del matrimonio entre personas libres de la misma raza, poco hicieron las autoridades angloamericanas para reforzar la autoridad del padre. Las colonias y estados aprobaron leyes que requerían el consentimiento de los padres, la mayoría de las veces, hasta que una hija cumplía 18 años y un hijo cumplía 21 años, aunque la ley generalmente castigaba a los infractores con multas, no con la anulación del matrimonio, tal como establecía la ley del Parlamento Británico de 1753 contra los matrimonios clandestinos. Los angloamericanos nunca implementaron esta ley, que permaneció vigente en Inglaterra hasta $1837,{ }^{114} \mathrm{y}$ tampoco muchas autoridades estatales se movilizaron para reforzar los requisitos de autorización hasta principios del siglo XX. ${ }^{115}$

A pesar de que la ausencia de una iglesia establecida y de un sistema central de registro de matrimonio probablemente habría hecho que cualquier legislación de los estados fuese difícil de aplicar, la deficiencia burocrática no es la explicación completa. La actitud desganada hacia el control de los matrimonios de hijos e hijas iba de la mano con otra característica angloamericana: el laxo compromiso del jefe de familia con el fondo conyugal de su descendencia. Los angloamericanos, como los ingleses, tenían libertad testamentaria para desheredar. En los hechos, pocos padres lo hicieron, pero los propietarios angloamericanos también fueron particularmente tímidos al especificar dotes y transferencias premortem. No había un sistema regularizado de contratos matrimoniales como con los franceses, ni cartas dotales o contratos de arras como en España o América Latina. Incluso en Inglaterra, un jefe de familia adinerado estaba limitado por el fideicomiso familiar, lo que no fue el caso en Estados Unidos. En los Estados Unidos ha sido muy difícil para los historiadores establecer la época del fin formal a la dote porque desde siempre fue un proceso informal. ${ }^{116}$ Esta timidez se asocia a la ausencia de preocupación por el futuro del linaje. Mientras que, en teoría, el gran 
poder individual del jefe de familia debería haber significado un control más estricto sobre la descendencia, sobre quién y cuándo se casaba, en la práctica, el hecho de perder el reconocimiento a las obligaciones de linaje y establecer procedimientos para negociar la dote aparentemente llevó cada vez más a los hijos a ignorar sus obligaciones de linaje. Durante la mayor parte del siglo XVIII, la formación de parejas sin intervención de los padres puede haber sido desalentada a través del enjuiciamiento y castigo de la fornicación y la bastardía. Pero, después que los azotes, las multas y citaciones públicas ante los tribunales fueron reemplazados, hacia fines del siglo XVIII y principios del siglo XIX, por medidas más benignas como los compromisos de pagar la manutención de los niños ilegítimos, las parejas arriesgaban cada vez menos en tomar la iniciativa de su propia relación. ${ }^{117}$ Las tasas inusualmente altas de embarazo prematrimonial e ilegitimidad en este período, varias décadas antes que se produjeran aumentos similares en Europa occidental, se han interpretado como indicadores del colapso del control parental sobre el sistema matrimonial. ${ }^{118}$ La mayoría de los países europeos también registraron aumentos en la ilegitimidad algunos años después que en los Estados Unidos. Y cada vez más, cuando las localidades perseguían la fornicación, lo hacían solo respecto de los casos que involucraban a personas no libres, parejas interraciales, o algún disturbio de la paz. ${ }^{119}$ Los patrones matrimoniales detallados en $\mathrm{A}$ Midwife's Tale de Laura Tatcher Ulrich ${ }^{120}$ indican que los jóvenes angloamericanos de Hallowell, Maine, alrededor del año 1800, tenían tanta consideración de la opinión de los padres sobre el matrimonio como la juventud de los Estados Unidos en la actualidad.

81 Fue en el contexto de este débil sistema de linaje que ciertos cambios económicos específicos, como la apertura de nuevos territorios, el crecimiento del empleo no agrícola y la creciente liquidez de los bienes muebles plantearon amenazas para el gobierno familiar. La incapacidad legal de los padres para controlar los matrimonios y la formación de hijos e hijas en el hogar, así como la desaparición de las severas sanciones contra las erráticas relaciones de pareja, permitieron a los jóvenes migrar libremente y proporcionaron incentivos para escapar de la supervigilancia de padres y amos, alojándose fuera del hogar. Cuando el gobierno y los especuladores abrieron nuevas extensiones de tierra, no había nada que impidiera la formación de nuevos hogares. Cuando los jóvenes abandonaban el hogar para tomar un nuevo trabajo, ya sea en una fábrica, oficina, aula, o incluso trabajo familiar, crecientemente buscaban alojarse fuera del hogar del padre o amo. ${ }^{121}$ Del mismo modo, los maduros legisladores varones comenzaron a cuestionarse la coverture de las mujeres no solo porque el crecimiento de activos líquidos, ocasionado por la creación de una infraestructura financiera en los Estados Unidos, hizo más fácil para los yernos derrochadores malgastar las propiedades de sus esposas, sino también porque este cambio ocurrió en el contexto de matrimonios que, crecientemente, eran decididos por los mismos contrayentes y no por sus padres. ${ }^{122} \mathrm{La}$ coverture, la servidumbre empleada o forzosa, e incluso la esclavitud parecían menos incongruentes en sociedades donde los hijos permanecían bajo el poder del jefe de familia hasta que se casaban o morían y los padres tenían la autoridad legal para detener el matrimonio de las hijas mientras más del $90 \%$ de ellas realmente se casaba. En Estados Unidos, los poderes ampliados que los amos habían obtenido sobre su fuerza laboral se asociaron con inmigrantes, deudores, indigentes o afroamericanos. No es sorprendente que los hombres blancos nacidos en América, enardecidos con el lenguaje republicano, llegaran a pensar que cualquier servicio que restringiera sus movimientos era inapropiado para ellos y tomaran a mal tener que competir con jefes de hogar que poseían su trabajo. Se ha argumentado que 
las mujeres fueron más ambivalente que los hombres en dar la bienvenida a la liberación sexual, porque podían ser más fácilmente seducidas y abandonadas. ${ }^{123} \operatorname{Sin}$ embargo, la aprensión femenina respecto de las nuevas reglas de emparejamiento promovió la soltería, no una renovada autoridad patriarcal.

En Europa y en otras partes de las Américas también fluyeron fuertes corrientes contrarias al control patriarcal sobre el matrimonio. Por ejemplo, en América Latina, no se debe suponer que los decretos borbónicos que requerían el consentimiento de los padres redundaron en una ordenada formación de los hogares. Durante el siglo XIX, se estima que en muchos países el $30-50 \%$ de los nacimientos ocurrieron fuera del matrimonio y una proporción similar tenía mujeres jefas de hogar. ${ }^{124}$ La vigilancia del matrimonio por parte de los padres, la iglesia y el estado parecía acaso desalentar la participación en ritos formales. Los hijos naturales de uniones consensuadas aunque no sancionadas por la iglesia fueron aceptados como herederos de su padre si el padre los reconocía como tales y legalmente pudiera haber contraído matrimonio con su madre. ${ }^{125}$ Importantes segmentos de la población, como los indígenas que vivían en sus propias comunidades, nunca habían aceptado por completo el linaje hispano y su sistema de matrimonio. ${ }^{126}$

La observancia del sistema se limitó a los sectores más hispanos de la población y a la élite propietaria. Entre este grupo, las nuevas reglas indudablemente colocaron barreras más formidables en el camino de los hijos e hijas que se casaban a pesar de las objeciones de un padre o una madre viuda. Sin embargo, la situación se complicó por la disminución del compromiso de los padres con un sistema de dote a fines del siglo XVIII y principios del XIX. En partes de México colonial, al menos, la carta dotal de la familia de la novia y el contrato de arras ofrecidas por el novio acompañaron alrededor de las tres cuartas partes de los matrimonios registrados en los siglos XVII y principios del XVIII. La proporción cayó a fines del siglo XVIII, y las transferencias casi desaparecieron de los registros notariales a principios del siglo XIX. ${ }^{127}$ No hay evidencia de que los padres comenzaron a desheredar a sus hijos, pero parecían menos dispuestos a hacer transferencias formales de cantidades significativas de recursos en el matrimonio, y esta falta de voluntad parece ser consistente con un sistema de matrimonio que se estaba volviendo cada vez menos administrado por los padres.

Sin embargo, en México, los hijos e hijas permanecieron bajo patria potestad hasta la promulgación del Código Civil 1870, el cual limitaba el control del matrimonio por parte de los padres a los menores de 21 años y especificaba que las hijas solteras podían abandonar la residencia parental a los 30 años. En el código de 1884, los padres obtuvieron libertad testamentaria, y ya no tuvieron que dar partes iguales de la herencia a sus hijos e hijas. Este cambio fue controvertido porque significó un abandono de las tradiciones legales de Europa continental y del pasado colonial en favor de la costumbre inglesa. Los innovadores escribieron con entusiasmo sobre cómo Inglaterra, "esa gran nación... que es hoy la más libre y quizás la más civilizada del mundo", tenía libertad testamentaria y cómo esa libertad "estimula a la ciudadanía a dedicarse a su trabajo...la fuente de virtudes públicas y privadas". ${ }^{128}$

Con la desaparición de la carta dotal y el contrato de arras, la propiedad del linaje de una novia ya no estaba protegido como lo había estado antes. El Código Civil de 1870 permitía a las esposas elegir entre mantener el control de sus propiedades heredadas o la mitad de su interés en la sociedad conyugal. ${ }^{129}$ Esta era una decisión sensible a las preocupaciones por el linaje. Sin embargo, el divorcio no estuvo disponible en México 
hasta el siglo XX, e incluso hoy en algunas partes de América Latina el divorcio no es una opción para las mujeres. América Latina tuvo guerras coloniales por la independencia y nunca expandió el poder del amo tan completamente como en Angloamérica, sin embargo, la considerable obligación de los miembros del hogar con el linaje significaba que su sistema de gobierno familiar fue más resistente que la forma angloamericana. ${ }^{130}$

Al excluir al gobierno patriarcal de los hogares de la historia política de los períodos colonial y nacional temprano, se excluyen la mayoría de las relaciones políticas en la población. Es imposible incorporar género, raza y clase en una narrativa política coherente cuando la discusión se limita a los tratos gubernamentales entre hombres blancos libres y propietarios. En este artículo he especulado sobre cómo podría escribirse una historia del gobierno familiar en los Estados Unidos. La hegemonía de la corona británica privilegió una versión inglesa de la autoridad doméstica con un jefe de familia poderoso y un sistema de apoyo sobre el linaje comparativamente débil. Estas características no desaparecieron en la América británica, aunque inicialmente el gobierno familiar angloamericano se enfrentó a una serie de desafíos por parte de los sistemas nativos americanos competidores, por factores demográficos y por las agendas de los colonos disidentes religiosos. Estos desafíos contribuyeron a crear en los euroamericanos un fuerte sesgo en contra de las formas matrilineales y matrifocales de organización del hogar, así como a los desafíos de la comunidad a la autoridad de los jefes de hogar. Irónicamente, la disponibilidad de tierra, cuando se combinó con un mercado en auge para los bienes de plantación, alentó la expansión de la autoridad patriarcal del hogar sobre los dependientes más allá de sus dimensiones del Viejo Mundo, al igual que la aversión religiosa y republicana al establecimiento de instituciones públicas. Las contribuciones inmediatas de la Guerra de la Independencia para revertir esta tendencia parecen modestas cuando se considera que la retórica de la libertad revolucionaria tardó más de una generación en aplicarse para abolir las dependencias legales de los hogares.

Cuestiono el hecho que la activación de estos discursos de libertad dependiera de alguna mega revolución del mercado o de la desaparición del hogar como lugar de producción. Más bien, creo que debería centrarse más la atención en la interacción entre cambios económicos específicos y un sistema de linaje débil. Se suponía que los patriarcas controlaban el movimiento de sus dependientes; cuando ya no pudieron hacerlo, el sistema se vino abajo.

Debido a que gran parte de la población de los Estados Unidos estaba sujeta al hogar en lugar del gobierno civil, la desintegración de estas dependencias legales a mediados del siglo XIX resultó en el crecimiento de los servicios públicos, el establecimiento reacio de un estado de bienestar y nuevos estatutos separatistas de ciudadanía. En consecuencia, el destino del gobierno familiar es fundamental para comprender el desarrollo político y la evolución de las políticas públicas en los Estados Unidos actuales y en la mayoría de los estados nacionales contemporáneos. 


\section{NOTAS}

1. Ver George Elliott Howard, A History of Matrimonial Institutions, vol. I (Chicago, 1904), caps. 1, 2; Peter Laslett, ed., Patriarcha and Other Political Works of Sir Robert Filmer (Oxford, 1949); James Casey, The History of the Family (Oxford, 1989), cap. 1; y Gordon J. Schochet, Patriarchalism in Political Thought: The Authoritarian Family and Political Speculation and Attitudes Especially in Seventeenth-Century England (Oxford, 1975).

2. Christopher Hill, Society and Puritanism in Pre-Revolutionary England, 2d ed. (New York, 1967), 443-82; Edmund S. Morgan, The Puritan Family: Religion and Domestic Relations in Seventeenth-Century New England, rev. ed. (New York, 1966).

3. Daniel Scott Smith, "The Meanings of Family and Household: Change and Continuity in the Mirror of the American Census", Population and Development Review, 18 (1992), 431, utiliza el término "diádico" para describir relaciones en la familia y enfatiza que los poderes del jefe de familia derivaban de la autoridad que poseía el marido, padre o amo, y no a la posición social de jefe de familia. William James Booth en Households: On the Moral Architecture of the Economy (Ithaca, 1993) y Christopher L. Tomlins en Law and Authority as Subjects in Labor History, American Bar Foundation Working Paper No. 9,312 (1993) son más receptivos a la idea de agrupar estas relaciones. Como se indica en el título de sus trabajos, estos autores se enfocan en el papel de las relaciones domésticas en la evolución de las relaciones económicas, mientras que este artículo enfatizará la relación con la formación del estado.

4. Ver Booth, Households, pt. 1.

5. Hale, The Analysis of the Law (London, 1716), 41-50; Blackstone, Commentaries on the Laws of England, ed. Thomas M. Cooley (Chicago, 1884), bk. I, 422. El tratado de Hale fue originalmente compuesto a mediados del siglo XVII. El trabajo de Blackstone fue publicado casi un siglo después. Ver también la primera definición de economía en el Oxford English Dictionary. Hale definió una tercera categoría de relaciones civiles: entre el ancestro y su heredero, el propietario y su arrendatario, el tutor y su pupilo, y el señor y el villano.

6. Discutir la transformación del concepto "económico" en el largo plazo demandaría un artículo separado. Sospecho, sin embargo, que la razón inicial para pedir prestado el término del ámbito del hogar tuvo más que ver con entregarle primacía a las actividades privadas en la generación de la riqueza y disminuir la importancia de las políticas gubernamentales, más que con nociones que buscaban liberar a la producción de las relaciones jerárquicas del hogar, o separar la producción del ámbito doméstico.

7. Sobre el concepto de domus ver David Herlihy, Medieval Households (Cambridge, Mass., 1985), 3. Sobre los tempranos textos del periodo republicano ver Zephaniah Swift, A System of the Laws of the State of Connecticut, 2 vols. (New York, 1972; pub. orig. 1795), I, 183-224; Tapping Reeve, The law of baron and femme; of parent and child; of guardian and ward; of master and servant; and of the powers of courts of chancery (New Haven, 1816); y James Kent, Commentaries on American Law, 13th ed., vol. 2 (Boston, 1884), 129-266.

8. Ver una revisión de la literatura sobre Inglaterra en Hill, Society and Puritanism, cap. 13, las fuentes americanas son citadas David Hackett Fischer, Albion's Seed: Four British Folkways in America (New York, 1989), 274-80, y Robert J. Steinfeld, The Invention of Free Labor: The Employment Relation in English and American Law and Culture, 1350-1870 (Chapel Hill, 1991), 58. Sobre el uso de "familia" en la antigüedad Greco-Romana y el temprano periodo medieval ver Herlihy, Medieval Households, 2-4.

9. Ver Herlihy, Medieval Households, y Jack Goody, The Development of the Family and Marriage in Europe (Cambridge, 1983). 
10. Ver, por ejemplo, los poderes descritos en Gerda Lerner, The Creation of Patriarchy (New York, 1986), cap. 4, 5, y en Jane Gardner, Women in Roman Law and Society (Bloomington, Ind., 1986), cap. 2.

11. Lawrence Stone, The Family, Sex, and Marriage in England, 1500-1800 (New York, 1977), 121-218. Stone es probablemente el más influyente historiador de la familia de la Inglaterra tempranomoderna. Sus críticos incluyen a Linda Pollock, Forgotten Children: Parent-Child Relations from 1500 to 1900 (Cambridge y New York, 1983), passim, y John R. Gillis, For Better, For Worse: British Marriages, 1600 to the Present (New York, 1985), 4-5.

12. Stone, Family, Sex, and Marriage, 121-218.

13. Carole Shammas, Marylynn Salmon y Michel Dahlin, Inheritance in America: From Colonial Times to the Present (New Brunswick, N. J., 1987), 23-30.

14. Susan Staves, Married Women's Separate Property in England, 1660-1833 (Cambridge, 1990).

15. Alan Macfarlane, The Origins of English Individualism: The Family, Property, and Social Transitions (New York, 1979), aborda el individualismo del jefe de hogar inglés pero no lo conecta con el estado o con el sistema de linaje.

16. James Axtell, ed., Indian Peoples of Eastern America: A Documentary History of the Sexes (New York, 1981).

17. Ibid., 110, 119, 113-14, 86, 92, 161. Los comentarios de Champlain están en Karen Anderson, Chain Her by One Foot: The Subjugation of Woman in Seventeenth-Century New France (London and New York, 1991), 131.

18. Helen C. Rountree, Pocahontas's People (Norman, Okla., 1990), 8; Peter C. Mancall, Valley of Opportunity: Economic Cultural along the Upper Susquehanna 70,0 -1800 (New York, 1991), 40; Kathryn E. Holland Braund, "Guardians of Tradition and Handmaidens to Change: Women's Roles in Creek Economic and Social Life during the Eighteenth Century", American Indian Quarterly, 14 (1990), 252; Joan M. Jensen, "Native American Women and Agriculture: A Seneca Case Study", en Ellen Carol DuBois y Vicki L. Ruiz, eds., Unequal Sisters: A Multicultural Reader in U. S. Women's History (New York, 1990), 62; Ramon A. Gutierrez, When Jesus Came, the Corn Mothers Went Away: Marriage, Sexuality, and Power in New Mexico, 1500-1846 (Stanford, 1991), 76.

19. Axtell, ed., Indian Peoples of Eastern America, 104.

20. Ibid., 110, 134.

21. White, The Middle Ground: Indians, Empires, and Republics in the Great Lakes Region, 1650-1815 (Cambridge, 1991), 61.

22. Braund, "Guardians of Tradition," 241-43; Anderson, Chain Her by One Foot, 107; Gutiérrez, When Jesus Came, 15; Daniel K. Richter, The Ordeal of the Longhouse: The Peoples of the Iroquois League in the Era of European Colonization (Chapel Hill, 1992), 20.

23. Axtell, ed., Indian Peoples of Eastern America, 83.

24. Ibid., 7, 12, 24, 33-34, 39, 42, 82, cita en 7; Rountree, Pocahontas's People, 69; Braund, "Guardians of Tradition", 241; Patrick Frazier, The Mohicans of Stockbridge (Lincoln, Neb., 1992), 97-99.

25. Frazier, Mohicans of Stockbridge, 36, 74, 76-77, 80, 86-87, 90, 94, 134-35; Gutierrez, When Jesus Came, 72-73.

26. Axtell, ed., Indian Peoples of Eastern America, 107, 7, 90, 10, citas en 107, 90.

27. Marcia Guttentag y Paul F. Secord, Too Many Women? The Sex Ratio Question (Beverly Hills, Calif., 1983), 115, 118.

28. Rountree, Pocahontas's People, 141-42. Terri Snyder, "'Rich Widows are the Best Commodity this Country Affords': Gender Relations and the Rehabilitation of Patriarchy in Virginia, 1660-1700" (Ph.D. diss., University of Iowa, 1992), cap. 6, discute las disposiciones de esta ley sobre el mestizaje.

29. John Cushing, ed., The Earliest Printed Laws of North Carolina, 1669-1751, 2 vols. (Wilmington, Del., 1977), 1, 130. Kirsten Fischer, “Contesting the Boundaries: Servant Women and Sexual Regulation 
in Colonial North Carolina" (paper delivered at the 1994 American Historical Association annual meeting), discute las duras penas asociadas a las relaciones interraciales en la colonia.

30. David D. Smits, “'We Are Not to Grow Wild': Seventeenth-Century New England's Repudiation of Anglo-Indian Intermarriage", American Indian Culture and Research Journal, 2, No. 4 (1987), 3, 16 (cita), 21-22.

31. Braund, "Guardians of Tradition", 250-51.

32. Russell Thornton, basándose en el trabajo de Sheila Ryan Johansson sostiene que las poblaciones devastadas por enfermedades epidémicas tienen la capacidad de recuperar gran parte del tamaño de su población dentro de unas cuantas generaciones si las condiciones son favorables. El problema en este territorio que se convertiría en los Estados Unidos es que las guerras, conquistas y subyugación acompañaron a las epidemias. Ver Thornton, "North American Indians and the Demography of Contact: Population Dynamics and Epidemic Disease following 1492", paper presented at the History of Health and Nutrition in the Western Hemisphere conference, Columbus, Ohio, Sept. 17, 1993. Ver también Johansson, “The Demographic History of the Native Peoples of North America: A Selected Bibliography," Yearbook of Physical Anthropology, 25 (1982), 133-52.

33. White, Middle Ground, 508

34. Ver Gutierrez, When Jesus Came, cap. 8, y Patricia Seed, To Love, Honor, and Obey in Colonial Mexico: Conflicts over Marriage Choice, 1574-1821 (Stanford, 1988), passim. En áreas dominadas por los angloamericanos, las sociedades nativas americanas como los iroqueses, quienes lograron mantener cierto espacio y tierras separadas, también retuvieron aspectos de su parentesco y formas de organización doméstica. Ver Richter, Ordeal of the Longhouse, 261-62, Jensen, "Native American Women", 51-65, y Nancy Shoemaker, "The Rise or Fall of Iroquois Women", Journal of Women's History, 2, No. 3 (1991), 39-57.

35. Robert E. McCaa, Introduction to "Female and Family in Nineteenth-Century Latin America", Journal of Family History, 16 (1991), 211-14.

36. Lewis H. Morgan, League of the Iroquois (New York, 1962; orig. pub. 1851), y Ancient Society (New York, 1877); Engels, The Origin of the Family, Private Property, and the State, trad. Alec West (New York, 1942; pub. orig. 1877).

37. Ver, particularmente, Russell R. Menard, "Immigrants and Their Increase: The Process of Population Growth in Early Colonial Maryland", en Aubrey C. Land et al., eds., Law, Society, and Politics in Early Maryland (Baltimore, 1977), 88-110; Lois Green Carr y Lorena S. Walsh, "The Planter's Wife: The Experience of White Women in Seventeenth-Century Maryland", William and Mary Quarterly, 3d Ser., 34 (1977), 542- 57 Walsh, “'Till Death Us Do Part': Marriage and Family in Seventeenth-Century Maryland", en The Chesapeake in the Seventeenth Century: Essays on AngloAmerican Society, ed. Thad W. Tate y David L. Ammerman (Chapel Hill, 1979) 126-52; Darrett B. y Anita H. Rutman, “Now-Wives and Sons-in-Law': Parental Death in a Seventeenth-Century Virginia County," ibid., 153-82; Carr, "Inheritance in the Colonial Chesapeake", en Ronald Hoffman y Peter J. Albert, eds., Women in the Age of the American Revolution (Charlottesville, Va., 1989) 155-210; T. H. Breen, “A Changing Labor Force and Race Relations in Virginia, 1660-1710", Journal of Social History 7, (1973), 3-25; Edmund S. Morgan, American Slavery, American Freedom: The Ordeal of Colonial Virginia (New York, 1975); Allan Kulikoff, Tobacco and Slaves: The Development of Southern Cultures in the Chesapeake 1, 680-1800 (Chapel Hill, 1986), caps. 1, 2, 5; Gloria L. Main, Tobacco Colony: Life in Early Maryland, 1650-1720 (Princeton, 1982), caps. 2, 3; y Snyder, "Rich Widows are the Best Commodity", caps. 1,2.

38. Daniel Scott Smith, "Meanings of Family and Household", 432.

39. Norton, "Gender and Authority in Early America; or A Tale of Two Women," paper delivered at the Eighth Berkshire Conference on the History of Women, June 10, 1990; William Bradford, of Plymouth Plantation, 1620-1647 ed. Samuel Eliot Morison (New York, 1952), 121. 
40. Morgan, Puritan Family, 45; Elizabeth Pleck, Domestic Tyranny: The Making of Social Policy Against Family Violence from Colonial Times to the Present (New York, 1987), 17-18 D. Kelly Weisberg, "Under Great Temptations Heer: Women and Divorce Law in Puritan Massachusetts", en Weisberg, ed., Women and the Law: The Social Historical Perspective, vol. 2 (Cambridge, Mass., 1982), 117-31.

41. Morgan, Puritan Family, 87-88, y Fischer, Albion's Seed, 130-32.

42. Lyle Koehler, A Search for Power: The "Weaker Sex" in Seventeenth-Century New England (Urbana, Ill., 1980) El Apéndice i establece un listado de todas las demandas de divorcio que aparecen en los registros judiciales y legislativos del siglo XVII en las colonias de Nueva Inglaterra. Una versión corregida de estas demandas aparece en Cornelia Hughes Dayton Women before the Bar: Gender, Law, and Society in Connecticut, 1640-1790 (Chapel Hill, N.C. 1995). De 118 demandas, las autoridades concedieron 98. De estas, 27 fueron concedidas por motivos como la impotencia que hubiese permitido la nulidad del matrimonio en Inglaterra. Hacia 1700, la población euroamericana de Nueva Inglaterra alcanzaba aproximadamente las 90,000 personas; John J. McCusker y Russell R. Menard, The Economy of British America, 1607-1789 (Chapel Hill, 1985), 103.

43. Koehler, Search for Power, 137, 140-41, muestra que, entre 1630 y 1699, 128 hombres y 57 mujeres fueron acusados de abusar de sus cónyuges. De las 27 esposas abusadoras sentenciadas en el condado de Essex, 2 fueron condenadas a latigazos, 20 obtuvieron multas en un rango entre 10 chelines y 2 libras esterlinas, y 5 recibieron solo amonestaciones. Martha Porter Saxton, "Being Good: Moral Standards for Puritan Women, Boston: 1630-1730" (PhD. diss., Columbia University, 1979) 175-77 también nota que $20 \%$ de las víctimas de asesinos hombres fueron sus esposas, mientras que tan solo una esposa enfrentó cargos por matar a su marido. Dayton, Women before the Bar, cap. 3, cree que la persecución de los esposos por golpear a sus mujeres fue más frecuente en el siglo XVII en Massachusetts y Connecticut, pero identifica solo 9 denuncias de mujeres abusadas entre 1710 y 1780 en el condado estudiado. Roger Thompson, Sex in Middlesex: Popular Mores in a Massachusetts County, 1649-1699 (Amherst, Mass., 1986), 10-11, encuentra 11 condenas en el periodo de 50 años estudiado en el condado Middlesex, donde la población creció de 3,000 a 10,000. Además, casi todos los casos ocurrieron antes de 1663.

44. Morgan, Puritan Family, 148-49; David H. Flaherty, Privacy in Colonial New England (Charlottesville, Va., 1972), 196; Daniel Scott Smith, "Meanings of Family and Household", 40.

45. Thompson, Sex in Middlesex, 31-33, detalla las actividades de este ejército de oficiales en hacer cumplir las normas de la comunidad.

46. J. William Frost, The Quaker Family in Colonial America: A Portrait of the Society of Friends (New York, 1973), 56, 79, 181; Barry Levy, Quakers and the American Family: British Settlement in the Delaware Valley (New York, 1988), 80-82; 139, 212-13; Jean R. Soderlund, “Women's Authority in Pennsylvania and New Jersey Quaker Meetings, 1680-1760”, WMQ, 3d Ser., 44 (1987), 722-49.

47. Fischer, Albion's Seed, 89-91, resume este trabajo en base a las investigaciones de Daniel Scott Smith y Michael S. Hindus, Robert V. Wells, Roger Thompson, y particularmente ensayos en Laslett et al., eds., Bastardy and Its Comparative History: Studies in the History of Illegitimacy and Marital Nonconformism. . (Cambridge, Mass., 1980).

48. Dayton, Women before the Bar, cap. 4.

49. Smith y Hindus, "Premarital Pregnancy in America, 1640-1971: An Overview and Interpretation", Journal of Interdisciplinary History, 5 (1975), 554, estima una tasa de condena de $61 \%$ de todas las parejas casadas que probablemente concibieron un hijo fuera del matrimonio para la década de 1670 s.

50. Dayton, Women before the Bar, cap. 4. En New Haven, la fornicación fue el crimen más común hacia los 1690s, superando a la ebriedad y al robo. Thompson, Sex in Middlesex, no entrega datos separados para los crímenes sexuales respecto otro tipo de ofensas, pero la fornicación aparentemente estaba en aumento a lo largo del siglo XVII. Hendrick Hartog, "The Public Law of a County Court: Judicial Government in Eighteenth-Century Massachusetts", American Journal of Legal History, 20 (1976), 282-329 muestra que se había convertido en el crimen más común hacia la 
década de 1720s. William E. Nelson, Americanization of the Common Law: The Impact of Legal Change on Massachusetts Society, I 1760-1830 (Cambridge, Mass., 1975), 37, muestra que tuvo este estatus en todo Massachusetts a mediados del siglo XVIII.

51. Martin Ingram, Church Courts, Sex, and Marriage in England, 1570-1640 (Cambridge, 1987) cap. 7.

52. Koehler, Search for Power, gráficos 12.1, 12.3, 12.4.

53. N.E.H. Hull, Female Felons: Women and Serious Crime in Colonial Massachusetts (Urbana, Ill., 1987), $61,67,129$.

54. Para una buena descripción de este proceso a finales del siglo XVII en Virginia ver Snyder, "Rich Widows are the Best Commodity," esp. cap. 6.

55. Hartog, "Public Law of a County Court", 301; Dayton, Women before the Bar, 152; Smith y Hindus, "Premarital Pregnancy in America", Appendix I.

56. Daniel Scott Smith, "American Family and Demographic Patterns and the Northwest European Model", Continuity and Change, 8 (1993), 402.

57. Philip J. Greven, Jr., Four Generations: Population, Land, and Family in Colonial Andover, Massachusetts (Ithaca, N. Y., 1970).

58. Ver Shammas, "A New Look at Long-Term Trends in Wealth Inequality in the United States", American Historical Review, 98 (1993), 412-31, y Daniel Scott Smith, "Female Householding in Late Eighteenth-Century America and the Problem of Poverty", J. Soc. Hist., 28 (1994), 83-107.

59. Este número es el estimado en 1774; Alice Hanson Jones, American Colonial Wealth: Documents and Methods, 2d ed., 3 vols. (New York, 1977), III, 1787.

60. Richard Starke, The Office and Authority of a Justice of the Peace (Williamsburg, Va., 1774), 318-20.

61. Deborah Gray White, "Female Slaves: Sex Roles and Status in the Antebellum Plantation South", en DuBois y Ruiz, eds., Unequal Sisters, 22-33.

62. Ver Peter Karsten, “'Bottomed on Justice': A Reappraisal of Critical Legal Studies Scholarship Concerning Breaches of Labor Contracts by Quitting or Firing in Britain and the U. S., 1630-1880" Am. J. Legal Hist., 34 (1990), 213-61; Steinfeld, Invention of Free Labor; Karen Orren, Belated Feudalism: Labor, the Law, and Liberal Development in the United States (Cambridge,1991); y Tomlins, Law, Labor, and Ideology in the Early American Republic (New York, 1992).

63. Steinfeld, Invention of Free Labor, 44.

64. Steinfeld, ibid., 121, sostiene que hacia mediados del siglo XVIII los sirvientes empleados podían renunciar sin ser perseguidos criminalmente, pero Karsten, "Bottomed on Justice," 218, argumenta que los trabajadores agrícolas en Inglaterra todavía eran condenados y encarcelados por amenazar la renuncia o por dejar a sus empleadores en el tercer cuarto del siglo XIX.

65. Ver James Davis, The Office and Authority of a Justice of the Peace (New Bern, N. C., 1774) 248, 310-12, y Starke, Office and Authority of a Justice, 318-20. Snyder, "Rich Widows are the Best Commodity", cap. 6, aborda el desarrollo de estas leyes a finales del siglo XVII en Virginia.

66. The Country and Town Officer (Boston, 1768), 84. Es interesante comparar la edad de los niños pobres y huérfanos enviados en aprendizaje por las parroquias en los registros del vigilante de pobres en el condado de Frederick, Virginia, estudiado por Holly Brewer ("Patriarchalism in the New Republic", tesis de doctorado en progreso, UCLA) con las edades mucho mayores en Inglaterra citadas en W. Newman Brown, "The Receipt of Poor Relief and Family Situation, Aldenham, Hertfordshire, 1630-1690," en Richard M. Smith, ed., Land, Kinship, and Life Cycle (Cambridge, 1984), 416-19. Brewer encontró una edad promedio de 8 años para los niños blancos en la década de 1750, y un promedio de 5,6 años para los negros y mulatos. Esto incluye a los huérfanos que podrían o no haber sido sometidos al aprendizaje sino hasta más tarde. En cambio, en la parroquia inglesa estudiada por Brown, los niños eran sostenidos hasta la edad de 12 o 14 años.

67. Michael Dalton, The Country Justice (London, 1655, orig. pub. 1618), 102, 112; Blackstone, Commentaries b, k. I, 458, bk. IV, 65; Country and Town Officer, 80, 84. 
68. Peter J. Coleman, Debtors and Creditors in America: Insolvency, Imprisonment for Debt, and Bankruptcy 1607-1900 (Madison, Wis., 1974), 142, 144, 147, y passim. Esta ley fue modificada en 1730, pero la servidumbre involuntaria por deuda no fue abolida en Pennsylvania sino hasta 1810. 69. Trabajos recientes sobre el strict family settlement, a veces también referido como el marriage settlement porque normalmente se ocasionaba con el matrimonio del heredero varón son Eileen Spring, "The Family, Strict Settlement, and Historians", Canadian Journal of History, 18, (1983) 379-98, "The Strict Settlement: Its Role in Family History", Economic History Review, 2d Ser., 41 (1988) 454-60,y "The Heiress-at-Law: English Real Property Law from a New Point of View", Law and History Review, 8 Otoño 1990, 273-96. Estos artículos entregan una bibliografía completa del trabajo de H. J. Habakkuk, Lawrence y Jeanne Stone, Lloyd Bonifield, y otros sobre el strict family settlement.

70. Shammas et al., Inheritance in America, 56.

71. Amy Louise Erickson, "Common Law Versus Common Practice: The Use of Marriage Settlements in Early Modern England”, Econ. Hist. Rev., 2d Ser., 43, No. 1 (1990), 28-29 estima que aproximadamente $2 \%$ de los casos de cancillería entre 1558 y 1714 se relacionaban con lo que ella entiende como marriage settlements. Estas no eran necesariamente propiedades separadas, pero aseguraban al menos una cierta cantidad vitalicia a favor de la esposa al momento de enviudar, y por tanto la protegían de la veleidad del testador.

72. Staves, Married Women's Separate Property, caps. 5, 6; Erickson, "Common Law Versus Common Practice", 21-39 El desarrollo de los procedimientos de equidad para proteger a la mujer casada bajo coverture [feme covert] está tratado en Maria L. Cioni, Women and Law in Elizabeth and England with Particular Reference to the Court of Chancery (New York, 1985).

73. Erickson, "Common Law Versus Common Practice", 31-35 argumenta que $10 \%$ de los documentos testamentarios examinados incluyen alguna forma de marriage settlement, por el cual se refiere ya sea a una disposición que requiere que a su muerte el marido entregue un cierto monto a su esposa o a sus hijastros, o bien una disposición que asegura la separación de bienes de la mujer. Solo 4 casos, equivalentes a 1/9 de la muestra, caían en la categoría de separación de bienes, y $1 / 9$ de un $10 \%$ equivale por tanto al $1-2 \%$ a los que me refiero. Mi propia experiencia con testamentos en los cuales las mujeres con propiedades separadas son las testadoras apoya esta cifra del 1-2\%, pues esta su incidencia habitual en las muestras de testamentos. Más de la mitad de los casos que Erickson cita son fianzas establecidas para asegurar que el segundo marido de una mujer albacea pagara las porciones debidas a los hijos del primer matrimonio. Estas cláusulas de ninguna forma aseguraban la propiedad de la mujer, sino el linaje paterno de su primer marido. Esto explica que la cifra que entrego respecto de los marriage settlements difiere de la de Erickson.

74. Ver texto y nota 92.

75. Jay Fliegelman, Prodigals and Pilgrims: The American Revolution against Patriarchal Authority, 1750-1800 (Cambridge, Mass., 1982); Melvin Yazawa, From Colonies to Commonwealth: Familial Ideology and the Beginnings of the American Republic (Baltimore, 1985).

76. Cathy N. Davidson, Revolution and the Word: The Rise of the Novel in America (New York, 1986).

77. Linda K. Kerber, Women of the Republic: Intellect and Ideology in Revolutionary America (Chapel Hill, 1980) Jan Lewis, "The Republican Wife: Virtue and Seduction in the Early Republic," WMQ, 3d Ser., 44 (1987) 689-721 y "Motherhood and the Construction of the Male Citizen in the United States, 1750-1850", en Constructions of the Self ed. George Levine (New Brunswick, N. J., 1992), Paula Baker, "The Domestication of Politics: Women and American Political Society, 1780-1920" AHR, 89 (1984), 623; Norma Basch, "From the Bonds of Empire to the Bonds of Matrimony: The Emerging Right of Divorce in the Context of American Independence," paper delivered at the 1990 meeting of the Organization of American Historians.

78. Pateman, The Sexual Contract (Stanford, 1988), cap. 4; Cynthia S. Jordan, “'Old Words' in 'New Circumstances': Language and Leadership in Post-Revolutionary America”, American Quarterly, 40 
(1988), 491-513 nota que un nuevo grupo de símbolos patriarcales que recurrían a la figura de George Washington como padre de la patria emergieron en la temprana era republicana.

79. Kerber revisa esta literatura en "Separate Spheres, Female Worlds, Woman's Place: The Rhetoric of Women's History", Journal of American History, 75 (1988), esp. 20-21.

80. Joan Hoff, Law, Gender, and Injustice: A Legal History of U. S. Women (New York, 1992) caps. 2, 3.

81. Kerber, "The Paradox of Women's Citizenship in the Early Republic: The Case of Martin vs. Massachusetts, 1805”, AHR, 97 (1992), 378.

82. Shammas, "Early American Women and Control over Capital", en Hoffman y Albert, eds., Women in the Age of the American Revolution, 134-35 y "Re-assessing the Married Women's Property Acts", J. Women's Hist., 6 (1994) 9-30.

83. Schultz, "Two Hundred Years of Divorce in Pennsylvania: Past Trends and Implications for the Future", en Charles Babbitt, ed., Sociology toward the Year 2000 (Harrisburg, Pa., 1983), 317. Como punto de comparación, la tasa de divorcio por 1000 habitantes en 1980 era de 5,4.

84. Considerando la falta de datos confiables sobre los matrimonios, la única medida uniforme para los divorcios en la América temprana son los divorcios por 1000 habitantes. Las estadísticas de divorcio que se entregan aquí consideran solo (1) divorcios con disolución de vínculo, no la mera separación de cuerpos, y (2) divorcios concedidos, no demandas de divorcio. Es un desafío el volver comparables las estadísticas de divorcio del periodo debido a la variedad de formas en que se ha calculado la disrupción del vínculo marital, y la escasez de datos estimados de población. Al realizar estas generalizaciones, he utilizado las siguientes fuentes, modificando los números cuando fue necesario para transformar las demandas en divorcios concedidos y para excluir a los divorcios sin separación de vínculo. Las fuentes son Schultz, "Two Hundred Years of Divorce in Pennsylvania", "Divorce in Early America: Origins and Patterns in Three North Central States", Sociological Quarterly, 25 (1984), 511-25 y “Divorce Patterns in Nineteenth-Century New England”, J. Family Hist., 15 (1990), 101-15; Nancy F. Cott, "Divorce and the Changing Status of Women in Eighteenth-Century Massachusetts", WMQ, 3d Ser., 33 (1976), 586-614, y Sheldon S. Cohen, "To Parts of the World Unknown: The Circumstances of Divorce in Connecticut, 1750-1797", Canadian Review of American Studies, 11 (1980), 275-93 y “The Broken Bond: Divorce in Providence County, 1749-1809", Rhode Island History, 44 (1985), 67-79.

85. Por ejemplo, ver Salmon, Women and the Law of Property in Early America, 99-100, donde una mujer de Pennsylvania intentó en 1790 obtener un divorcio en Connecticut. Ver también Jackson v. Jackson, 1 New York (1 William Johnson), 324 (1806), donde un tribunal de Nueva York denegó la pensión alimenticia a una mujer neoyorquina que había viajado a Vermont para obtener su divorcio, y Inhabitants of Hanover v. Turner, 14 Mass. (13 Tyng), 327 (1817), en el cual un divorcio obtenido por un hombre de Massachusetts en Vermont fue declarado nulo. Neal R. Feigenson, "Extraterritorial Recognition of Divorce Decrees in the Nineteenth Century", Amer. J. Legal Hist., 34 (1990), 120-67 revela el fracaso de los estados en llegar a cualquier tipo de acuerdo para el reconocimiento de los divorcios a lo largo del siglo XIX. En la mayoría de los casos, quienes viajaban a otro estado con el expreso motivo de divorciarse, probablemente encontrarían que su divorcio era nulo si lo hubiesen sometido a su verdadero estado de residencia.

86. Sobre las causales y procedimientos de divorcio en el temprano periodo republicano ver Salmon, Women and the Law of Property, cap. 4; Hartog, "Marital Exits and Marital Expectations in Nineteenth Century America", Georgetown Law Journal, 80 (1991), 95-129; Dayton, Women before the Bar, cap. 3; Basch, "Bonds of Empire to Bonds of Matrimony"; Merril D. Smith, Breaking the Bonds: Marital Discord in Pennsylvania, 1730-1830 (New York, 1991); y los artículos de Martin Schultz citados en la nota 84.

87. Las demás causales contenidas en las leyes-bigamia, impotencia, consanguinidad-en realidad eran causales de nulidad y no representaban ninguna divergencia sustancial de los mecanismos ya presentes en el derecho canónico.

88. Salmon, Women and the Law of Property, 211. 
89. Ibid., 71-76; y Hartog, "Marital Exits and Marital Expectations", 98-110.

90. Dean v. Richmond, 23 Mass. (5 Pickering), 465 (1827). Esta opinión fue utilizada para justificar el otorgamiento de los poderes de feme sole [mujer soltera] a la mujer casada, para que pudiese subvenir a su propia manutención.

91. Grossberg, Governing the Hearth: Law and the Family in Nineteenth-Century America (Chapel Hill, 1985), cap. 8.

92. Realizo un resumen de los hallazgos de Marylynn Salmon, Suzanne Lebsock, y Richard Chused en Shammas, "Re-assessing the Married Women's Property Acts".

93. Fliegelman, Prodigals and Pilgrims; Yazawa, From Colonies to Commonwealth; Daniel Blake Smith, Inside the Great House: Planter Family Life in Eighteenth-Century Chesapeake Society (Ithaca, N.Y., 1980); Lewis, The Pursuit of Happiness: Family and Values in Jefferson's Virginia (Cambridge, Mass., 1984); Jacqueline S. Reiner, "Rearing the Republican Child: Attitudes and Practices in PostRevolutionary Philadelphia", WMQ, 3d Ser., 39 (1982), 110-65; Steven Mintz, "Regulating the American Family", J. Family Hist., 14 (1989), 392-93.

94. Brewer, "Under the Protection of the State? Children's Rights 1750-1820", paper presented at the Early American History Seminar, Huntington Library, Mar. 20, 1993

95. Robert W. Fogel, Without Consent or Contract: The Rise and Fall of American Slavery (New York, 1989), 206.

96. Ira Berlin, Introduction a Berlin y Hoffman, eds., Slavery and Freedom in the Age of the American Revolution (Charlottesville, Va., 1983), xv-xxvii; Fogel, Without Consent or Contract, 206-07; Robin Blackburn, The Overthrow of Colonial Slavery, 1776-1848 (New York, 1988), 111-30; Donald R. Wright, African Americans in the Early Republic, 1789-1831 (Arlington Heights, Ill., 1993), cap. 1.

97. Steinfeld, Invention of Free Labor, cap. 5.

98. El crecimiento del apoyo a las instituciones patriarcales en el periodo anterior a la Guerra Civil de 1861-1865 se discute en Eugene Genovese, The World the Slaveholders Made (New York, 1969), y Elizabeth Fox-Genovese, Within the Plantation Household: Black and White Women of the Old South (Chapel Hill, 1988).

99. Mintz, "Regulating the American Family", 394.

100. Wilentz, "Society, Politics, and the Market Revolution, 1815-1848", en Eric Foner, ed., The New American History (Philadelphia, 1990), 54.

101. Lawrence M. Friedman, A History of American Law (New York, 1973), 186; Elizabeth Bowles Warbasse, The Changing Legal Rights of Married Women (New York, 1987), cap. 4; Chused, "Married Women's Property Law", 1414-1425; Salmon, "Republican Sentiment, Economic Change, and the Property Rights of Women in American Law", en Hoffman y Albert, eds., Women in the Age of the American Revolution, 447-75.

102. Forest Chester Ensign, Compulsory School Attendance and Child Labor (Iowa City, Iowa, 1921), 204.

103. Ver ibid., passim, y Patrick M. Horan y Peggy G. Hargis, "Children's Work and Schooling in the Late Nineteenth-Century Family Economy”, American Sociological Review, 56 (1991), 591-93.

104. Alexis de Tocqueville, Democracy in America, 2 vols., ed. Philips Bradley (New York, 1945), II, 192.

105. Silvia Marina Arrom, The Women of Mexico City, 1790-1857 (Stanford, 1985), esp. cap. 2.

106. Henrie de Bracton, On the Laws and Customs of England, trans. Samuel E. Thorne (Cambridge, Mass., 1968), II, 35. Bracton, refiriéndose a la situación en el siglo XIII, reporta que los hijos legítimos estaban en la potestad del padre, o, en el caso que siguiera vivo, en la de su abuelo, hasta que se les otorgara la herencia a los hijos o muriera el abuelo.

107. Shammas et al., Inheritance in America, 83-88.

108. Seed, To Love, Honor, and Obey in Colonial Mexico.

109. Gutierrez, When Jesus Came, 271-78.

110. Seed, To Love, Honor, and Obey in Colonial Mexico, 134. 
111. Gutierrez, When Jesus Came, 315-18. Ver también Stone, Road to Divorce: England 1530-1987 (Oxford, 1990), 55-58, 80-81, 96-120, y T. S. Hanley, "Engendering the State: Family Formation and State Building in Early Modern France", French Historical Studies, 16 (1989), 4-27.

112. Seed, To Love, Honor, and Obey in Colonial Mexico, 201, 203.

113. Ibid., 205-25.

114. Gillis, For Better, For Worse, 110, 140-42, 196.

115. Howard, Matrimonial Institutions, III, 191 n. 2; Grossberg, Governing the Hearth, 85-88, 141, 148.

116. Jane Lambiri-Dimake, "Dowry in Modern Greece: An Institution at the Crossroads between Persistence and Decline", en Marion A. Kaplan, ed., The Marriage Bargain: Women and Dowries in European History (New York, 1985), llama la atención respecto del contraste que existe entre la ausencia de una historia de la dote en los Estados Unidos, y la persistencia de la obligación dotal en países como Grecia donde se mantuvo hasta finales del siglo XX.

117. Respecto del momento en que ocurrieron los cambios en la persecución penal y las leyes de Nueva Inglaterra, ver Nelson, Americanization of the Common Law, 110-111; Hartog, !Public Law of a County Court!, 282-329; y Dayton, Women before the Bar, cap. 4. Sobre los cambios en Carolina del Norte, ver Donna J. Spindel, Crime and Society in North Carolina, 1663-1776 (Baton Rouge, 1989), 62-63.

118. Smith y Hindus, "Premarital Pregnancy in America 1640-1971". Para las cifras europeas, ver Edward Shorter, "Illegitimacy, Sexual Revolution, and Social Change in Modern Europe", 2n Theodore K. Rabb y Robert I. Rotberg, eds., The Family in History: Interdisciplinary Essays (New York, 1973), 48-84.

119. Victoria E. Bynum, Unruly Women: The Politics of Social and Sexual Control in the Old South (Chapel Hill, 1992), 182, encuentra que en las localidades cubiertas por su estudio en Carolina del Norte antes de la Guerra Civil la mayoría de los casos de fornicación en los que la raza y el estatus jurídico del acusado podía ser determinado implicaban a parejas interraciales, parejas de esclavos liberados, o parejas en las que el marido estaba previamente casado.

120. Ulrich, A Midwife's Tale: The Life of Martha Ballard, Based on Her Diary, 1785-1812 (New York, 1990).

121. Mucho se ha escrito últimamente sobre la relación entre la cultura juvenil y las crecientes oportunidades sexuales en las grandes ciudades de inicio del siglo XIX. Ver las descripciones de la vida social de las personas empleadas en el comercio antes de la Guerra Civil en Patricia Cline Cohen, "Unregulated Youth: Masculinity and Murder in the 1830s City", Radical History Review, No. 52 (1992), 33-53, la vida social de las mujeres obreras en Christine Stansell, City of Women: Sex and Class in New York, 1789-1860 (New York, 1986), y el crecimiento de la prostitución, los deportes masculinos y las pensiones de alojados en Nueva York después de 1820 en Timothy J. Gilfoyle, City of Eros: New York City, Prostitution, and the Commercialization of Sex, 1790-1920 (New York, 1992), 17-116.

122. Peggy A. Rabkin, Fathers to Daughters: The Legal Foundation of Female Emancipation (Westport, Conn., 1980), presenta el argumento que el ímpetu a favor de las reformas de la legislación sobre la propiedad de las mujeres casadas en Nueva York provino de los padres ansiosos de proteger su propiedad de sus yernos.

123. Este asunto estuvo al corazón del debate entre Edward Shorter y Louise Tilly, Joan Scott y Miriam Cohen. Para una reciente discusión sobre este debate centrado en Europa más que en Estados Unidos ver Wally Seccombe, A Millennium of Family Change: Feudalism to Capitalism in Northwestern Europe (New York, 1992), 227-29.

124. Elizabeth Kuznesof y Robert Oppenheimer, "The Family and Society in Nineteenth Century Latin America: An Historiographical Introduction", J. Family Hist., 10 (1985), 217, y McCaa, "Introduction", J. Family Hist., 16 (1991), 211-12. Este último número del Journal of Family History contiene 6 artículos sobre concubinato, ilegitimidad y abandono de niños. 
125. Linda Lewin, "Natural and Spurious Children in Brazilian Inheritance Law from Colony to Empire: A Methodological Essay", The Americas, 48 (1992), 351-96.

126. La renuencia de los indígenas a adoptar el matrimonio cristiano en los siglos XVII y XVIII parece plausible considerando la discrepancia entre las cifras de población y de matrimonio. Ver Gutierrez, When Jesus Came, 92, 167, 271-97. Esta diferencia ocurría a pesar de que la Iglesia renunciaba a realizar el control prenupcial para descubrir si existían impedimentos a una unión entre indios viviendo en la misma parroquia.

127. Edith Couturier, "Women and the Family in Eighteenth-Century Mexico: Law and Practice", J. Family Hist., 11 (1985), 301. Couturier hace referencia al trabajo de Muriel Nazzari sobre São Paulo, Brasil, el que muestra una caída en la proporción de la riqueza familiar entregada a través de dotes aproximadamente en el mismo periodo Nazarri, "Women and Property in the Transition to Capitalism: Decline of the Dowry in São Paulo, Brazil (1640-1870)", paper presented at American Historical Association annual meeting, 1984.

128. Citado en Arrom, "Changes in Mexican Family Law in the Nineteenth Century: The Civil Codes of 1870 and 1884", J. Family Hist., 10 (1985), 314.

129. Ibid., 312.

130. Para un resumen sobre derecho de familia en América Latina ver Nancy Folbre, Who Pays for the Kids?: Gender and the Structures of Constraint (New York, 1994), 242-45.

\section{NOTAS FINALES}

i. N. del T.] Concepto Angloamericano derivado de la legislación normanda que dictaba un estatus legal de subordinación a la mujer casada. La mujer antes del matrimonio era plenamente libre de contratar y de administrar su voluntad como quisiera. Sin embargo, cuando se casaba, esta pasaba a ser una "unidad marital", un concepto jurídico donde marido y mujer eran considerados una sola persona: el marido. Es decir, la mujer perdía su personalidad legal al contraer matrimonio y era absorbida por la persona del marido

ii. [N. del T.] El "separate but equal" o "separados pero iguales" fue una doctrina legal surgida a finales del siglo XIX, tras la Guerra Civil norteamericana, que interpretaba que la segregación racial no se podía considerar como violatoria de la $14^{\mathrm{a}}$ enmienda de la Constitución norteamericana, la cual garantiza la igualdad ante la ley. En base a ella, la Corte Suprema norteamericana se negó a declarar inconstitucional las "Jim Crow Laws" que mantenían en pie el sistema de segregación racial en EE. UU.

iii. [N. del T.] Una traducción literal es "sirviente con librea". La librea era un atuendo o uniforme típico feudal que los nobles hacían llevar a sus criados como símbolo de su propio estatus. Bajo este concepto, el "liveried retainer" era aquel servidor del aristócrata que llevara puesta una librea.

\section{RESÚMENES}

Este ensayo de síntesis interpretativa ilumina el proceso de configuración y desintegración de gobierno familiar en los Estados Unidos desde el periodo colonial hasta mediados del siglo XIX, a partir de una perspectiva comparada con el caso Hispanoamericano. A partir de ello, demuestra cómo el poder formal dentro de los hogares es uno de los elementos principales que conecta el 
desarrollo político de la Angloamerica Colonial con el de los Estados Unidos, y constituye un aspecto esencial de la historia política del estado-nación.

El artículo muestra cómo el gobierno familiar en Angloamérica colonial se estructuró primero en base a la confrontación del modelo inglés de autoridad doméstica con la organización del hogar en culturas nativas americanas, especialmente en lo relativo a roles de género, pues muchas culturas indígenas eran matrilineales. Ello, junto con los desafíos comunales y demográficos propios en los asentamientos angloamericanos, y en particular, la necesidad de control sobre sirvientes y esclavos, llevó a la creación de un modelo de autoridad patriarcal reforzada en comparación con el caso inglés, al mismo tiempo que se redujeron las obligaciones del padre de familia para con su linaje.

La Revolución Americana tuvo pocos efectos a corto plazo en la organización del gobierno familiar, toda vez que no se materializó ningún movimiento significativo tendiente a abolir la esclavitud, la servidumbre, la coverture de las esposas, o el trabajo infantil. No fue sino con el crecimiento económico de mediados del siglo XIX que comienza a observarse una desintegración de la autoridad familiar. Con todo, el mercado no puede ser considerado el solo responsable de estos cambios: la estructura legal del gobierno familiar angloamericano, y en especial la debilidad de las obligaciones respecto del linaje -en comparación con el caso Hispanoamericano- explican por qué la autoridad familiar del padre fue progresivamente erosionada en Estados Unidos, mientras que logró mantenerse por mucho mayor tiempo en América Latina.

\section{ÍNDICE}

Mots-clés: genre, famille, anglo-Amérique, période coloniale, histoire politique

Keywords: gender, family, anglo-America, colonial period, political history

Palabras claves: género, familia, anglo-América, periodo colonial, historia política

\section{AUTORES}

\section{CAROLE SHAMMAS}

Profesora Emérita y John R. Hubbard Chair Emerita in History de la Universidad de Southern California. Este artículo fue inicialmente presentado en el Huntington Library Early American History Seminar, y la autora desea agradecer a los participantes por sus comentarios. 